\title{
THE ARGUMENTS OF LAW, POLICY AND PRACTICE AGAINST SWISS-TYPE PATENT CLAims
}

\author{
Daniel Armstrong*
}

Swiss-type patent claims were first recognised by Switzerland in 1984 as a means of permitting drug manufacturers to gain patent protection following the discovery of a known substance's second or subsequent medical use. Despite dubious legal foundations, particularly the questionable existence of sufficient novelty, Swiss-type claims have been accepted in Europe, England, and, in a recent Court of Appeal decision, New Zealand. Additionally troublesome is that the dominant reason for their acceptance has been the drive for uniformity in national patent laws, a desire that precluded consideration of the various negative practical consequences of accepting such claims. This topic has received little academic comment and this essay redresses that in the most assertive of ways by arguing that Swiss-type claims are illegal, primarily due to a lack of novelty, and that they should be illegal for various reasons of policy and practice.

\section{INTRODUCTION}

"We do not have oil, copper, gold, silver, gas, anything", observes Johannes Randegger, a representative of Swiss-based pharmaceutical giant Novartis. "We have mountains and our brains ... and for patent applications and number of Nobel Prize winners, we are within the top group." ${ }^{1} \mathrm{Mr}$ Randegger's pride is based on Switzerland's long history of achievement in a range of fields where intellect is employed in the most creative and demanding ways. The excellence achieved by Rolex, Victorinox, Lindt, and other household names ensures that in a

* This paper was submitted in fulfilment of the LLB(Hons) requirements at Victoria University in 2000.

1 Anonymous "Chemical Industry Continues to Invest in Research" The Washington Times, Washington DC, United States, 20 January 2000 <http://www.washtimes.com/internatlads/switzerland/20.html> (last accessed 30 September 2000). 
diverse range of fields, "Swiss made" connotes the use of high skill, precision craftsmanship, and inventive techniques.

Switzerland's intellectual productivity reaches its pinnacle in the pharmaceutical and chemical industries. The export sales of Swiss-based multinational drug companies like Novaris and Hoffman La Roche brought 26.0 billion Swiss francs into Switzerland in $1996 .{ }^{2}$ Drug manufacturing is a pillar in the Swiss economy; the industry employed 28,000 people in $1996^{3}$ and created immeasurable benefits for those in the industry's supporting infrastructure, including manufacturing contractors, ${ }^{4}$ suppliers of drug making equipment, advertising companies, empirical research companies, and export middle-men.

The manufacturers of Switzerland's expensive, high quality goods benefit greatly from trademark, passing off, industrial copyright, and patent laws. This essay focuses on patent law, and in particular a specific form of patent claim first recognised in 1984 by the Swiss Patent Office. Known today as a "Swiss-type claim", it greatly aids the Swiss economy by increasing the level of protection available to drug manufacturers.

The self-serving aspect of Swiss-type claims is accentuated by the compelling arguments why they should never have been introduced. At every stage of their expanding acceptance, from Switzerland, to Europe, to Britain and beyond, the legal legitimacy of Swiss-type claims has been suspect. Nor have the courts addressed the practical problems of allowing such claims. Yet Swiss-type claims survive, popping up in new jurisdictions like holes in the proverbial dyke. Ten months ago, Swiss-type claims received New Zealand's stamp of approval. ${ }^{5}$ Spurred by that decision, this essay raises a voice against this great "Swiss miss".

2 Elsbeth Altmann "Drugs and Pharmaceuticals (Switzerland) Industry Sector Analysis" (US \& Foreign Commercial Service and the US Department of State, Washington DC, 6 June 1998) <http://www.tradeport.org/ts/countries/switzerland/isa/isar0019.html> (last accessed 29 September 2000).

3 Swiss Health Website "The Pharmaceutical Industry" <http://www.swisshealth.ch/full/ pharma.htm> (last accessed 29 September 2000).

4 For example, Lonza Biologics, a member of the Swiss-based Alusuisse-Lonza Group. See "Swiss Pharamaceutical Manufacturer Lonza Biologics' US Investment Reaches \$58 Million" <http:/ / www.swissemb.org/ls/body_lonza.html> (last updated 6 January 2000).

5 Pharmaceutical Management Agency Ltd $v$ The Commissioner of Patents [2000] 2 NZLR 529 (CA). 


\section{SWISS-TYPE CLAIMS DEFINED AND EXPLAINED}

\section{A What Is a "Patent Claim"?}

In 1852 the United Kingdom began requiring patent applicants to file a complete specification of their patent's subject-matter. The complete specification was to describe the invention so the public could use it once the patent monopoly expired. The specification was also used to determine the patent's validity and scope. This duality of purpose was problematic because the invention's description, intended to facilitate understanding of its workings, could easily extend beyond the actual thing or method invented. In 1883, the United Kingdom introduced a requirement that patentees include within the complete specification a claim, or claims, to act as a distinct statement of the invention. "Claims", including Swiss-type claims, therefore define the scope of a patent monopoly. ${ }^{6}$

\section{B What is a "Swiss-Type Claim"?}

Swiss-type claims can most basically be described as a variety of "subsequent medical use" claim, made when someone discovers that a known drug has a previously unknown medical use. Beyond this the answer becomes complicated, for, as one English judge has remarked, understanding Swiss-type claims requires an initiation in the "Byzantine logic of patent law".7 To explain Swiss-type claims it is necessary to first explain why other, more intuitive forms of patent claim do not avail drug manufacturers.

\section{Aspirin example}

The drug aspirin will be used as an illustration. The active chemicals in aspirin are acetylsalicylic acids. These cling to protein cells, preventing them from producing prostagladins. Prostagladins play an important role in inducing swelling and causing our nervous system to register pain, hence Friedrich Beyer \& Co originally marketed aspirin as a drug to ease pain and swelling. But recently it was discovered that prostagladins also cause blood to clot. Blood clots are one cause of heart attacks, and so aspirin is now also used in the preventative treatment of heart attacks. If we imagine the position of the company responsible for discovering and proving this new use of aspirin, what types of patent claim could be made?

6 See generally Alan W White "The Function and Structure of Patent Claims" (1993) 15 EIPR 243. See also Evan's Medical Patent [1998] RPC 517, 576 (UK Pat Ct) per Laddie J: "[f]irst one must identify what the alleged invention is, that is to say what is covered by the claims of the patent...".

7 Bristol-Myers Squibb Co v Baker Norton Pharmaceuticals Inc [1999] RPC 253, 271 (UK Pat Ct) per Jacob J. 
There appear to be two possible "product claims" and two possible "use claims". A product claim is one where the subject-matter is a physical entity itself, whereas the subject-matter of a use claim is a physical activity, or series of activities, performed with or upon an entity. ${ }^{8}$ Use claims are also called method claims or process claims. Product and use claims can also be "purpose-limited", meaning that infringement will occur only if the patented product or use is replicated with the patented purpose in mind.

\section{Options one and two: product claims over the drug and/or active chemicals}

The two possible "product claims" in our aspirin example would patent either the aspirin medicament or acetylsalicylic acids themselves. However, these claims would be disallowed because only new products or uses can be patented, and the aspirin and acetylsalicylic acids already exist. ${ }^{9}$ Although the use is new, this would not assist the maker of a product claim.

A leading authority on this point is Adhesive Dry Mounting Co Ltd v Trapp $\mathcal{E}$ Co $^{10}$ ("Adhesive Dry Mounting"). The case concerned a thin membrane made from dipping tissue paper into a gum resin solution. An expired patent for the membrane itself had earlier been granted to $\mathrm{Mr}$ Jeyes, with its contemplated uses including use as tracing paper or for wrapping tea or tobacco. But following the discovery by members of the public that the membrane formed an adhesive when heated, a retailer sought to patent its use in "dry mounting" photographs and other documents onto cardboard or similar material. Parker J (later Lord Parker) decided as a matter of construction that the patentee's first claim was a use claim, and the second a product claim to the membrane itself. As regards the product claim, Parker J said, ${ }^{11}$

Jeyes does not suggest that this material can be used for mounting photographs, or any analogous purpose ... But after Jeyes's patent [expired] it was open to all the world to make and sell such a material. The idea of using an old material for an entirely new purpose, not being analogous to purposes for which it has theretofore been used, may be good subject-matter, but such idea, however ingenious, can hardly justify a claim for the material itself. [emphasis added]

8 Pyrrolidine Derivatives / Hoffmann-La Roche [1984] OJ EPO 174, Case T 128/82, point 1.3 (EPO); Alan W White "The Function and Structure of Patent Claims" (1993) 15 EIPR 243, 245.

9 The novelty requirement is discussed further below.

10 Adhesive Dry Mounting Co Ltd $v$ Trapp \& Co (1910) 27 RPC 341 (EWCA).

11 Adhesive Dry Mounting Co Ltd v Trapp \& Co (1910) 27 RPC 341, 353 (EWCA). 
This passage has been interpreted as saying that a mere "novelty of purpose" cannot uphold product claims. Yet implicit in Parker J's statement is that a use claim could succeed (the use claim in question failed because it was obvious). Therefore the case stands for the proposition that if a patent is sought over $X$ (whether a product or use), novelty must derive from $X$ itself. This rule is reflected in the Manuel of Patent Practice of the UK Patent Office, which states, "if the invention lies in a new method of using a known material only the new method can be claimed." ${ }^{\text {12 }}$ [emphasis added]

Importantly, the applicant's product claim might have succeeded in Adhesive Dry Mounting if the product underwent some material change so as to render it "novel". For example, a drug in pill-form taken to treat high blood pressure could not be re-patented if it was found to treat acne, but could be patented if reformulated from a pill into an ointment.

An important authority on the extent of differentiation necessary is Ciba-Geigy (Durr's) Application $^{13}$ ("Ciba-Geigy"). Patent protection was sought following the discovery that a herbicide known to affect dicotyledonous weeds could also be used against monocotyledonous weeds. The applicant made a product claim for the known herbicide, arguing the requisite novelty derived from the new instructions for the new use adorning the container. The English Court of Appeal rejected this argument, stating, ${ }^{14}$

There seems to us to be nothing inventive about parceling up the known material in any and every convenient package or container having written thereon the information that it can be used for the stated purpose in the stated loci ... . There is nothing novel in the mere presentation of information by ordinary writing or printing on a container.

Ciba-Geigy was decided under the UK's previous patent legislation, but subsequent cases show it still applies under the Patents Act 1977. In Bayer AG (Meyer's) Application 15 ("Bayer"), Bayer sought a patent following their discovery that a known compound was effective in treating cerebral disorders. However, a previous Bayer specification had disclosed this compound for use against heart disorders. This precluded a claim to the compound itself, so Bayer claimed a "commercial package" containing the compound plus instructions for its

12 Manual of Patent Practice [in the United Kingdom Patent Office] (4 ed, December 1999) para 2.43 <http://www.patent.gov.uk/dpatents/mpp/manual.html> (last viewed 29 September 2000).

13 Ciba-Geigy (Durr's) Application [1977] RPC 83 (EWCA).

14 Ciba-Geigy (Durr's) Application [1977] RPC 83, 89 (EWCA) per Russell LJ.

15 Bayer AG (Meyer's) Application [1984] RPC 11 (UK Pat Ct). 
newly discovered use against "cerebral insufficiency". These claims were rejected because the prior disclosure rendered the concept of packaging the drug obvious, and the mere presentation of information was deemed obvious by section 1 (2)(d) of the Patents Act 1977. ${ }^{16}$

So in our aspirin example, product claims for the aspirin or acetylsalicylic acids would fail for lack of novelty, notwithstanding their newly discovered use, unless the physical form of the aspirin medicament was sufficiently altered. Re-branding or re-packaging the aspirin with new instructions would not suffice.

\section{Option three: use claim over the use of the drug}

The third possibility for our hypothetical aspirin manufacturer is to patent the use of aspirin in treating heart attacks. This use claim avoids the novelty problem encountered by product claims because the patent is over the very thing from which novelty derives. Claims in the form, "use of known substance $X$ for new purpose $Y$ ", are thus generally acceptable. The leading Commonwealth authority on this is National Research Development Corp $v$ Commissioner of Patents, ${ }^{17}$ ("NRDC"). NRDC concerned claims over the use of known substances for the new purpose of weed control. The issue was whether a new use could rightfully be regarded as a patentable "invention", defined by statute as, "any method of new manufacture the subject of letters patent and grant of privilege within section 6 of the Statute of Monopolies...". ${ }^{18}$ The High Court of Australia concluded it could be, rejecting the view that "inventions" involved the production or alteration of a vendible or tangible product. ${ }^{19}$ NRDC was adopted in Ciba-Geigy, meaning that although the patentee's product claim over the herbicide was rejected (for want of novelty), their claim for using that herbicide against monocotyledonous weeds was allowed.

16 "Packaging-plus-instructions" claims are clearly non-patentable on a number of grounds. They were rejected in Ciba-Geigy for lack of novelty, in Bayer for non-inventiveness (obviousness), and, in another case Dow Corning Corporation (Bennett's) Applications [1974] RPC 235 (UK Pat Ct), for being a disguised attempt at patenting a method of medical treatment.

17 National Research Development Corp v Commissioner of Patents (1959) 102 CLR 252.

18 Patents Act 1952 (Cth), s 6 "invention".

19 This view had been articulated in Australia in Maeder v Busch (1938) 59 CLR 684, 706 per Dixon J. Referring to a method of permanently waving hair, Dixon J said, "the object is not to produce or aid the production of any article of commerce." This passage was adopted in New Zealand in Maeder $v$ "Ronda" Ladies' Hairdressing Salon [1943] NZLR 122, 177-8 (CA) per Myers CJ. See also Re GEC's Application (1942) 60 RPC 1 per Morton J. 
On NRDC alone, drug manufacturers could theoretically patent every new use of a drug. However, a well-established exception to this general rule precludes reliance upon NRDC in the area of medical use claims. Due to ethical considerations, patents on methods of medical treatment are widely prohibited. This prohibition, and its merits, are considered below when it is argued that Swiss-type claims unwisely undermine it. For now it suffices to observe that in our aspirin example a claim for, "the use of aspirin for treating heart attacks", would fail.

\section{Option four: use claim over the use of the active chemicals (Swiss-type claim)}

For drug manufacturers the unavailability of the above claims poses a conundrum; once the patent on a drug used for a particular purpose expires, they cannot secure a renewed exclusive right to make and sell that drug if a new use is found (or revealed to the public, as the case may be). Their salvation is the Swiss-type claim. It is a purpose-limited use claim that focuses not on the use of the drug, but on the use of the active chemicals to make the drug, side-stepping the prohibition on medical method of treatment patents. Specifically, the patentee claims the exclusive right to use the relevant active chemicals in manufacturing a drug for the new treatment purpose. A Swiss-type claim in our aspirin example would cover, "the use of acetylsalicylic acids to make aspirin for treating heart attacks."

Some might call Swiss-type claims creative, others inelegant, and one commentator has referred to their wording as "tortured". ${ }^{20}$ Nevertheless, the Swiss should be afforded some congratulations. Despite dubious legal status and clear and compelling policy reasons for disallowance, Swiss-type claims have taken root in both the civil and common law worlds, allowing manufacturers the world over the luxury of securing new patents and production rights for making old drugs.

In this author's opinion, it is time to remove this luxury. The assault against Swiss-type claims proceeds on two fronts; first the legal arguments are considered, followed by non-legal arguments focusing on the practical effects of their recognition.

\section{THE LEGAL ARGUMENTS AGAINST SWISS-TYPE CLAIMS}

Patent law is not a creature of common law. It is bound by and defined by legislation. A patent outside the wording of a jurisdiction's patent legislation is ultra vires and illegal. This

20 John R Thomas "Of Text, Technique, and the Tangible: Drafting Patent Claims Around Patent Claims" (1998) 17 J Marshall J Computer \& Info L 219, footnote 1. 
part of the essay argues that Swiss-type claims were not allowed under the laws of the various jurisdictions through which they have passed, primarily for lack of novelty.

\section{A Swiss-Type Claims in Europe}

\section{The European Patent Office and convention}

The European Patent Convention (EPC), in force since 1 June 1978, aims to harmonise the national laws of its Contracting States and to provide a more efficient system for Europe-wide patent registration. The European Patent Office (EPO) is the executive branch of the European Patent Organisation, a body established to adjudicate upon and register European patents. It was the EPO's Enlarged Board of Appeals (Enlarged Board) 1985 decision in Re Eisai Co Ltd ${ }^{21}$ ("Eisai") that first gave Swiss-type claims judicial approval, and thus legitimacy Previously, Swiss-type claims were only authorised by paragraph 243.4(b) of the Swiss Patent Office's Guidelines, $^{22}$

The use of a product for preparing an agent for surgical, therapeutic or diagnostic purposes, for example the processing of an active substance into a ready-to-use drug form. Such a claim is grantable. It can also be formulated if the use to which it relates is the second (or further) indication of a known drug substance.

As statutory creatures, a patent's validity predominantly raises questions of statutory interpretation. Eisai was an exercise in the interpretation of the EPC, specifically Articles 52(1), 52(4) and 54(5) of the EPC's English language version. ${ }^{23}$ Article 52(1) expresses three requirements for patentability: novelty, ${ }^{24}$ inventiveness, ${ }^{25}$ and industrial applicability. ${ }^{26}$ Article 52(4) contains the prohibition on patenting methods of treating humans "by surgery or

21 Re Eisai Co Ltd [1985] OJ EPO 64, Case GR 05/83.

22 English translation submitted by counsel for the patent applicant in John Wyeth $\mathcal{E}$ Brother Ltd's Application Schering AG's Application [1985] RPC 545 (UK Pat Ct).

23 The EPC has three authentic texts, one English, one French, and one German.

24 This disqualifies all things previously "made available to the public by means of a written or oral description, by use, or in any other way". This is the definition from EPC Article 54(2) of what is in the "state of the art".

25 This disqualifies all novel things that are too obvious from past disclosures.

26 This disqualifies all novel and non-obvious things that cannot be put to use, for instance due to a lack of clinical testing. 
therapy", and on patenting "diagnostic methods practiced on the human body". The prohibition operates through the legal fiction that such methods are incapable of industrial application.

\section{Eisai}

Eisai did not originally relate to Swiss-type claims. The decision arose because the EPO's Technical Board of Appeal for Chemistry, faced with seven separate appeals from rejected patent applications, all turning on the same issue, referred a question of law to the Enlarged Board. The seven appellants had all claimed the use of a product for treating humans, and the question was whether these were permissible under the EPC. While Article 52(4) would appear conclusive, the then-recent Hydropyridine ${ }^{27}$ decision of the German Bundesgerichtshof (Federal Court of Justice) had cast doubt on its effect. Faced with a claim for the use of a known substance in treating cerebral disorders (the same discovery considered in Bayer), the German court indicated that claims in the form "use of a known product to treat an illness" should be accepted. They felt such claims extended beyond a claim to a method of medical treatment because they incorporated the patentable acts of packaging and marketing the drug for its new use. $^{28}$

Hydropyridine gave heart to drug manufacturers, hence the rash of patent applications that produced the seven appeals decided by Eisai. But the Eisai Board rejected Hydropyridine, stating that such claims were identical to claims for a method of medical treatment and so excluded by Article 52(4). The Enlarged Board communicated this initial finding to the appellants, but also suggested that a type of claim then permitted in Switzerland might rescue them. Submissions on the legality of Swiss-type claims were invited, with the primary hurdle for the appellants being the requirement of "novelty" in Article 52(1).

The argument adopted by the Enlarged Board, which accorded Swiss-type claims the requisite novelty, relied upon a dubious interpretation of Article 54(5). The Article's first paragraph defines "novel" inventions as those outside the "state of the art", and paragraphs two through four explain that phrase. Article 54(5) then says that the preceding paragraphs, "shall not exclude the patentability of any [known] substance or composition ... for use in a method referred to in Article 52(4), provided that its use for any method referred to in that paragraph is

27 Hydropyridine [1984] OJ EPO 26 (German Fed Ct J).

28 See the discussion in Alan W White "The Function and Structure of Patent Claims" (1993) 15 EIPR 243, 248. 
not [known]." [emphasis added]. Article 54(5) thus allows a known product to be patented on the basis of its new medical use, even though that use is itself unpatentable due to Article 52(4). This is clearly an exception to the rule that a patent's novelty must derive from its subjectmatter.

But what is the specific type of claim allowed? The deliberate use of "any" is crucial because it limits Article 54(5) to purpose-limited product claims where a first medical use is discovered for an old substance. Discovery of a second or further medical use would not support a fresh patent. This is because by the time of the second use's discovery, the first medical use is already known, breaching the proviso that the drug be unknown for use in any method of medical treatment. $^{29}$

This interpretation of Article 54(5) involves no twisting of the words and accords with the stated intentions of several European delegates in EPC conference working papers. ${ }^{30}$ The simple rule framed in the EPC is that known substances can be re-patented upon discovery of a medical use, but not when further medical uses are discovered. This represents a balance between the competing concerns of promoting pharmaceutical research and maintaining freedom of action in the medical arena. Leaving for later discussion the question of whether this approach is defensible in principle, the fact remains that this was the law at the time of Eisai.

The Enlarged Board of Appeals did not feel constrained by this plain-language interpretation. Article 54(5) was not treated as a limited exception to the general requirements of patentability, and did not receive the narrow construction required. ${ }^{31}$ Instead, the Enlarged Board observed that Article 54(5) allowed the novelty for purpose-limited product claims over a known substance to be derived from the new medical use. They reasoned that if this type of

29 This interpretation is seemingly approved in Manual of Patent Practice [in the United Kingdom Patent Office] (4 ed, December 1999) paras 2.44-2.46 <http://www.patent.gov.uk/dpatents/mpp/ manual.html> (last viewed 29 September 2000).

30 Gerald D Paterson "The Patentability of Further Uses of a Known Product Under the European Patent Convention" (1991) 13 EIPR 16, 17.

31 See Harvard Oncomouse [1990] OJ EPO 476, Case T0015/90, where, speaking of another exception in the EPC, it was said, "Article 53(b) is an exception, for certain kinds of inventions, to the general rule under Article 52(1) that European patents "shall be" granted for all inventions which are susceptible of industrial application, which are new and which involve an inventive step. Any such exception must, as repeatedly pointed out by the Boards of Appeal, be narrowly constructed." See also Plant Genetic Systems Plant Cells [1995] OJ EPO 545, Case T0356/93. 
claim could draw novelty from a new medical use, so too could Swiss-type claims for the use of known substances in making known drugs. Secondly, the Board found no intention to limit the scope of Article 54(5) to first, and only first, medical uses of known products, meaning that Swiss-type claims could also draw novelty from second or subsequent uses. This blatantly ignored the use of "any" in Article 54(5). The Board's unconvincing argument was that the heuristic expressio unius est exclusio alterius ${ }^{32}$ could sometimes cause injustice.

The first four paragraphs of Article 54, which define "novelty", came from the Strasbourg Convention $1963^{33}$ and so Europe had experienced their operation. Conversely, Article 54(5) was derived from a specific form of patent only allowed in France, and then only until 1978. Its inclusion in the EPC introduced, in the words of the EPO, "a special concept of novelty unknown in other technical fields." 34 In 1974, the draft version of Article 54(5) was referred to as a "cuckoo's egg" because of its potential to supersede Europe's various rules of novelty. ${ }^{35}$ Eisai proved this prediction true. As a cuckoo grows larger than its surrogate parents expect, so too has Article 54(5) grown beyond its intended scope. Article 54(5) originally accorded novelty to product claims; Eisai expanded it to accord novelty to use (of active chemical) claims. Article 54(5) allowed novelty to be drawn from first medical uses only; Eisai allowed novelty to derive from second and subsequent uses as well.

This extension of Article 54(5) was supposedly "justifiable by analogy". ${ }^{36}$ But in actuality the Enlarged Board wrongfully distilled from a specific statutory exception a much wider rule, of potentially general application, allowing patent claims to succeed despite deriving novelty from something other than the patent's subject-matter.

32 "When one thing is expressed the alternative is excluded."

33 Strasbourg Convention on the Unification of Certain Points of Substantive Law on Patents for Invention 1963.

34 See Gerald D Paterson "The Patentability of Further Uses of a Known Product Under the European Patent Convention" (1991) 13 EIPR 16, footnote 5, citing [1984] OJ EPO 164, Case T128/82.

35 O Bossung "Invention and Patentability in European Patent Law" [1974] Mitteilung 101, 126. Cited in Gerald D Paterson "The Patentability of Further Uses of a Known Product Under the European Patent Convention" (1991) 13 EIPR 16.

36 Re Eisai Co Ltd [1985] OJ EPO 64, Case GR 05/83, para 21. 
The opportunity for a common law court to assess Swiss-type claims arose soon after, in John Wyeth \& Brother Ltd's Application / Schering AG's Application 37 ("Wyeth \& Schering").

\section{B Swiss-Type Claims in England}

\section{Wyeth \& Schering per Hearing Officer Bailey}

In two separate decisions in 1984 and 1985, Hearing Officer Bailey rejected Swiss-type claims for lack of novelty. The Wyeth claim was based on the discovery that certain guanidines, used for treating high blood pressure and ulcers, also prevented diarrhoea. The discovery behind the Schering claim was that certain aromatase-inhibitors, used to treat breast cancer, were effective against prostatic hyperplasia. Mr Bailey noted with an air of cynicism, "the pharmaceutical industry feels that there is a need to have a suitable way of claiming such alleged inventions." 38

Mr Bailey heard Wyeth's application before Eisai, but by the time of Schering's application the EPO's approval of Swiss-type claims was well known. Eisai was not binding, but was highly persuasive. EPC Articles 52(1), 52(4) and 54(5) are reproduced in sections 1(1), 4(2), and 2(6), respectively, of the UK's Patent Act 1977, and are deemed to have the same meaning as their European counterparts. ${ }^{39}$ The Act's recital states it is, "to give effect to certain international conventions on patents", including the EPC and when applying the Act, "any decision of, or expression of opinion by, the relevant convention court on any question arising under or in connection with the relevant convention", must be noted. ${ }^{40}$ Consequently the English judiciary has said they should, "work on the basis that the corresponding provisions of the $[\mathrm{EPC}]$ are of direct effect." 41

Nevertheless, Mr Bailey comfortably rejected Eisai and Swiss-type claims. He recognised the resulting anomaly that patents granted under the EPC might be refused in England, but he could not escape the clear meaning of section 2(6) (equivalent to EPC Article 54(5)). His key observation was that, "[w]hile it may be that the law has changed in respect of claims to known

37 John Wyeth E Brother Ltd's Application Schering AG's Application [1985] RPC 545 (UK Pat Ct).

38 John Wyeth \& Brother Ltd's Application Schering AG's Application [1985] RPC 545, 555 (UKPO).

39 Patents Act 1977 (UK), s 130(7).

40 Patents Act 1977 (UK), s 91(1).

41 Bristol-Myers Squibb Co v Baker Norton Pharmaceuticals Inc [1999] RPC 253, 258-259 (UK Pat Ct) per Jacob $\mathrm{J}$. 
substances and compositions which are being regarded as novel under section 2(6) ... I do not think that it necessarily follows that the same considerations should be applied generally." ${ }^{2}$ [emphasis added]. In other words, Mr Bailey recognised that Article 54(5) only permitted product claims based on a product's first medical use. Swiss-type claims fell outside the section's ambit because the presence of "any" meant that substances with previous medical uses were excluded, and secondly, because the section referred to product claims, not use (of chemicals to make a drug) claims.

Mr Bailey also applied this interpretation of section 2(6) to deny patents in Bayer and in Sopharma SA's Application. ${ }^{43}$

Mr Bailey also denied that novelty could be found independently of section 2(6). He identified the binding Court of Appeal decisions in Adhesive Dry Mounting and Ciba-Geigy as binding authorities for the proposition that new uses of products could not support patent claims to the products themselves. This, however, should not have been sufficient to dismiss the applicants' claims, for of course a Swiss-type claim is not over a known product itself but over the known process of making that product. The better approach would have been to derive from those cases the wider rule implicit therein that novelty in a patent over $\mathrm{X}$ must derive from $X$ itself.

Nevertheless, Mr Bailey reached the correct result in finding Swiss-type claims bereft of suitable novelty. This victory was unfortunately erased when both decisions were appealed to the Patent Court.

\section{Wyeth \& Schering per Falconer and Whitford JJ}

Sitting en banc, Falconer and Whitford JJ in the Patent Court were unable to fault $\mathrm{Mr}$ Bailey's interpretation of the Patents Act 1977 and case-law. They also were unconvinced by Eisai, saying, "we think the better view would be that a claim in the Swiss form ... would not be patentable as lacking the required novelty." 44 Yet on the verge of relegating Swiss-type claims to the status of historical footnote, they abandoned their legal reasoning for the ideal of conformity, concluding, ${ }^{45}$

42 John Wyeth \& Brother Ltd's Application Schering AG's Application [1985] RPC 545, 551 (UKPO).

43 Sopharma SA's Application [1983] RPC 195 (UKPO).

44 John Wyeth \& Brother Ltd's Application Schering AG's Application [1985] RPC 545, 565 (UK Pat Ct).

45 John Wyeth \& Brother Ltd's Application Schering AG's Application [1985] RPC 545, 567 (UK Pat Ct). 
Eisai's approach to the novelty of the Swiss type of use claim ... is equally possible under the corresponding provisions of the 1977 Act and, notwithstanding the opinion expressed earlier as to the better view of the patentability of such a Swiss-type claim ... having regard to the desirability of achieving conformity, the same [Eisai] approach should be adopted to the novelty of the Swiss type of claim.

English decisions following Wyeth $\mathcal{E}$ Schering generally omit reference to the hesitancy expressed by Falconer and Whitford JJ. ${ }^{46}$ Not until 1998 and Jacob J's judgment in Bristol-Myers Squibb Company $v$ Baker Norton Pharmaceuticals Inc 47 ("BMS") did judicial concern at the legality of Swiss-type claims and the "obvious difficulties with Eisai" 48 reappear.

\section{BMS per Jacob J}

BMS concerned taxol, an anti-cancer drug administered over a twenty-four hour infusion period. At issue was a Swiss-type patent granted in Europe for the use of taxol to manufacture a drug to administer over a three hour infusion period, with pre-medication, thereby reducing the risk of adverse side effects. Jacob J invalidated the patent because previous public lectures on taxol rendered the benefits of three hour infusions obvious. However, his Honour, was disturbed by the fact that were it not for this defect, the patent would have stood on the basis of Eisai. He posed the following hypothetical questions, ${ }^{49}$

Take a newly discovered use for aspirin (one was discovered not so long ago, namely its use to reduce risks of heart attacks). The manufacture of aspirin pills is old. So why is the manufacture rendered new because there is a new use? Or why does adding the purpose of the manufacture of aspirin to the claim make the manufacturing process any newer?

In this passage, His Honour recognised the difficulty in reconciling common sense with granting a patent for a manufacturing process that has been freely available for decades. Nevertheless, echoing Wyeth $\mathcal{E}$ Schering, he concluded, 50

46 See, for example, Hoerrmann's Application [1996] RPC 341 (UKPO), which simply records that Swisstype claims are accepted in England after Wyeth $\mathcal{E}$ Schering.

47 Bristol-Myers Squibb Co v Baker Norton Pharmaceuticals Inc [1999] RPC 253 (UK Pat Ct).

48 Bristol-Myers Squibb Co v Baker Norton Pharmaceuticals Inc [1999] RPC 253, 272 (UK Pat Ct) per Jacob J.

49 Bristol-Myers Squibb Co v Baker Norton Pharmaceuticals Inc [1999] RPC 253, 272 (UK Pat Ct).

50 Bristol-Myers Squibb Co v Baker Norton Pharmaceuticals Inc [1999] RPC 253, 272 (UK Pat Ct). 
UK courts must have regard to the decisions of the EPO on the construction of the EPC ... they are of great persuasive authority, first because they are decisions of expert courts ... involved daily in the administration of the EPC and secondly because it would be highly undesirable for the provisions of the EPC to be construed differently in the EPO from the way they are interpreted in the national courts of a Contracting State. ... It is a matter of the utmost seriousness for any court to depart from a decision of an Enlarged Board of the EPO on a point of law, and, if it is to be done at all by a national court, I think it should only be done by a higher national court and not one of first instance. For the sake of coherence of the system as a whole first instance courts should exercise self-restraint, however erroneous they may think a particular decision of law of an Enlarged Board may be. [emphasis added]

\section{BMS per Aldous, Buxton and Holman LJ}

Jacob J's decision was upheld on appeal, 51 although his thinly veiled disapproval of Eisai was tempered. Aldous LJ said, "[t]he patent judges in the John Wyeth case correctly summarised the approach of the Enlarged Board and I believe that they came to the right conclusion in the cases before them." 52 Buxton LJ concurred, "I do not think that it is open to us to act on those criticisms [of Eisai], even if they were thought to have force." 53

The Court rejected the contention that the presence of "any" in Article 54(5) limited that paragraph to discoveries of first medical uses. However, the Court's reasoning was highly contentious. Buxton LJ believed, "if the aim were to exclude from further patentability any substance already used in a medical application, art 54(5) could have simply said so." $54 \mathrm{He}$ then indicated that if Article 54(5) read, "provided that its use for any other method of treatment etc is not already [known]", its extension to accord Swiss-type claims novelty would not have happened. ${ }^{55}$ This was a startling conclusion. The only way His Honour's suggested wording

51 Bristol-Myers Squibb Co v Baker Norton Pharmaceuticals Inc (23 May 2000) LEXIS 2000 WL 664521, (EWCA).

52 Bristol-Myers Squibb Co v Baker Norton Pharmaceuticals Inc (23 May 2000) LEXIS 2000 WL 664521 (EWCA) para 37.

53 Bristol-Myers Squibb Co v Baker Norton Pharmaceuticals Inc (23 May 2000) LEXIS 2000 WL 664521 (EWCA) para 76.

54 Bristol-Myers Squibb Co v Baker Norton Pharmaceuticals Inc (23 May 2000) LEXIS 2000 WL 664521 (EWCA) para 80.

55 Bristol-Myers Squibb Co v Baker Norton Pharmaceuticals Inc (23 May 2000) LEXIS 2000 WL 664521 (EWCA) para 80. 
differed from the EPC was that, "any other method of treatment", was substituted for, "any method referred to in that paragraph [52(4)]". It borders on the absurd to argue a distinction in meaning since Article 52(4) does no more than describe the particular methods of medical treatment that cannot be patented.

Apart from this shaky legal reasoning, the decision also rested on the oft-invoked principle of conformity. This desire to foster homogenous patent law throughout Europe is understandable. Insular, nationalised lines of authority would shatter the ideal of a Europewide patent regime, inhibit European commerce and prevent English judges from influencing the development of European patent law. However, the fact that three years after Wyeth $\mathcal{E}$ Schering, the Appellate Division of the Netherlands Patent Office rejected Swiss-type claims casts doubt on the European unity that the English judiciary eagerly preserved. ${ }^{56}$

One can also argue that the desire for homogeneity should yield to the principled development of patent law. While it may be preferable for courts of first instance to "fall in line" with doubtful authorities, it is unfortunate that the English appellate courts have also felt constrained. Their inversion of the priority of making good law with that of maintaining consistency institutionalised Swiss-type claims in England, much to the benefit of UK pharmaceutical giants like Glaxo Wellcome and SmithKline Beecham. It also opened the door to the spread of these claims throughout the Commonwealth.

\section{Swiss-Type Claims in New Zealand}

New Zealand's approval of Swiss-type claims was also linked to conformity. On March 22, 1990, New Zealand's Commissioner of Patents issued a practice note stating that product claims for pharmaceuticials would be rejected if the alleged novelty only resided in a new use, 57

If the compounds are new such a claim is allowable. However, if the compounds are known, and their use in pharmaceutical compositions is known, such claims are not allowable even if the

56 See Gerald D Paterson "The Patentability of Further Uses of a Known Product Under the European Patent Convention" (1991) 13 EIPR 16, 18, referring to [1988] OJ EPO 405, Case 16673. Note, however, that this decision was effectively overturned when the Dutch Patent Law was amended in 1995. See also Todd Martin "Patentability of Methods of Medical Treatment: A Comparative Study" (2000) 82 J Pat \& Trademark Off Soc'y 381, footnote 131 and accompanying text.

57 The practice note is reproduced in Pharmaceutical Management Agency Ltd $v$ The Commissioner of Patents [2000] 2 NZLR 529, 531 (CA). 
particular pharmaceutical use is new. This is because the pharmaceutical composition prepared is not novel unless it is materially different from previous compositions; the fact that it is intended to be used to treat a medical condition different from that for which it has previously been used is irrelevant.

This statement accorded with Adhesive Dry Mounting and Ciba-Geigy. But on July 7, 1997, the Commissioner issued another practice note stating that Swiss-type claims would now be accepted to keep New Zealand in line with a "continuing international trend".58 The Pharmaceutical Management Agency Ltd ("Pharmac"), responsible for managing pharmaceutical subsidies in New Zealand, sought judicial review of the Commissioner's decision. The Commissioner did not oppose Pharmac alone, for twenty-five international drug manufacturers, plus the Researched Medicines Industry Association of New Zealand, applied to be joined as co-defendants. In Pharmaceutical Management Agency Ltd $v$ The Commissioner of Patents $^{59}$ ("Pharmac"), this coalition obtained a declaratory judgment from the Court of Appeal that Swiss-type claims were legal. ${ }^{60}$

New Zealand labours under the dated provisions of the Patent Act 1953, modelled on the repealed Patents Act 1949 (UK). There is no statutory prohibition on patenting methods of medical treatment, and no section like EPC Article 54(5) from which Swiss-type claims can leach novelty. However, these rules do exist in New Zealand case-law, with the result that our law as relevant to Swiss-type claims is similar to that of Europe and Britain.

The all-important requirement of novelty exists in our Act, albeit in a different form. ${ }^{61} \mathrm{New}$ Zealand allows patents for "inventions", defined as, "any method of new manufacture the

58 The practice note is reproduced in Pharmaceutical Management Agency Ltd $v$ The Commissioner of Patents [2000] 2 NZLR 529, 531 (CA).

59 Pharmaceutical Management Agency Ltd $v$ The Commissioner of Patents [2000] 2 NZLR 529 (CA).

60 The Court of Appeal upheld the decision of Gallen J in Pharmaceutical Management Agency Ltd $v$ The Commissioner of Patents [1999] RPC 752 (HC).

61 Note that in February 1992 the Ministry of Commerce published Reform of the Patents Act 1953: Proposed Recommendations, which recommended amending the Patents Act 1953 to include the EPC's three criteria for patentability: novelty, inventiveness and industrial applicability. See Philip Culbert "Patent Law Reform in New Zealand: Should Methods of Medical Treatment be Patentable?" [1997] 5 Patent World 32, 37. Amendment of the Act has been put on hold pending further consultation with Maori groups, particularly on the issue of patenting life forms. See Kenneth B Poplewell (NZPO Commissioner) "The TRIPs Agreement: Implementation and Enforcement" (Apec Industrial Property Rights Symposium, August 1996) <http://www.jpo-miti.go.jp/saikine/nz.htm> (last accessed 30 September 2000). 
subject of letters patent and grant of privilege within section 6 of the Statute of Monopolies [or] any new method or process of testing applicable to the improvement or control of manufacture". 62

The prohibition on patenting methods of medical treatment, codified in Article 54(2) of the EPC, exists in New Zealand through Wellcome Foundation Ltd $v$ Commissioner of Patents ${ }^{63}$ (discussed below).

New Zealand case-law also mirrors EPC Article 54(5) in permitting the discovery of a first pharmaceutical use of a known substance to support a purpose-limited product claim. In New Zealand, this rule exists because the courts accept that the requisite novelty comes from reformulating the known substance in a "pharmaceutically pure form". ${ }^{64}$ This reflects the rule that novelty must reside in a patent's subject-matter; the claim is a product claim and is permissible only because the court entertains the argument that the product becomes new through conversion into a pharmaceutically pure form. Gault J, who delivered the Court of Appeal's unanimous judgment in Pharmac, criticised this reasoning because it ignored the fact that the truly novel part of the invention lay in the new medical use. He said, ${ }^{65}$

The step necessary to render Swiss-type claims acceptable would be to recognise what is in fact the situation, that the novelty ... resides in the newly discovered purpose for which the medicament is to be used. That is the step the Enlarged Board took "by analogy" in the Eisai case.

Though it may be true to identify the new medical use as the immediate source of novelty, this novelty cannot support a multitude of different patent claims. It can only support a claim to that new medical use itself. The very fact that in order to permit a product claim the law relies on a legal fiction (that a pharmaceutically pure version of a substance is a "new" substance), shows that the novelty of the end-use is useful only to a point. This novelty of use cannot support a product claim, and nor should the Court have let it support a claim directed at the very different use claimed through the Swiss-type formulation.

62 Patents Act 1953, s 2 "invention".

63 Wellcome Foundation Ltd $v$ Commissioner of Patents [1983] NZLR 385 (CA).

64 Pharmaceutical Management Agency Ltd $v$ The Commissioner of Patents [2000] 2 NZLR 529, 539 (CA).

65 Pharmaceutical Management Agency Ltd $v$ The Commissioner of Patents [2000] 2 NZLR 529, 541 (CA). 
Gault J also referred to EI Du Pont de Nemours \& Co (Witsiepe's) Application, ${ }^{66}$ where Lord Wilberforce described the law relating to so-called "selection" patents. ${ }^{67}$ These patents are based on the discovery that chemicals selected from a previously known class have previously unrecognised advantages. As with "first pharmaceutical use" claims, selection patents involve a type of product claim where the true source of novelty is probably the product's end-use. But again this novelty is legally incapable of supporting a product claim. Instead, the product is deemed novel because the new, smaller group of chemicals is different from the larger class. ${ }^{68}$ While artificial, the reasoning underlying both "first pharmaceutical use" and "selection" patents is consistent with the rule that novelty must derive from a patent's subject-matter, and not from a related use or product which is not claimed.

Having illustrated the similarity in the laws underlying the patent regimes of New Zealand, Europe and England, Gault J concluded, 69

We have not been persuaded that there is anything in the New Zealand Patents Act or in the judicial decisions of this country which directly precludes a similar process of reasoning to that adopted in Eisai. We reject the contention that that decision was dictated by provisions of the EPC which are to be distinguished from the position in New Zealand.

In other words, the similarity of our laws with Europe's allowed Eisai's faulty derivation of novelty to be applied.

\section{Conclusions on the Legality of Swiss-Type Claims}

Swiss-type claims are directed to patenting the use of active chemical ingredients. They should be denied for want of novelty unless that use is novel, such as would occur if a different manufacturing process was used. The Eisai approach to finding novelty for such claims was unprincipled, and in the absence of a statutory provision to the contrary should be rejected. Article 54(5) of the EPC provided one such exception, allowing a particular type of purposelimited product claim to derive novelty from a novel end-use. But Eisai wrongly allowed novelty to be derived from a drug's new medical end-use even when it was a completely

66 E I Du Pont de Nemours \& Co (Witsiepe's) Application [1982] FSR 303 (HL).

67 E I Du Pont de Nemours \& Co (Witsiepe's) Application [1982] FSR 303, 309 (HL).

68 The New Zealand Court of Appeal had previously taken the view that selection patents were not permitted, see Beecham Group Ltd v Bristol-Myers Company [1981] 1 NZLR 600 (CA).

69 Pharmaceutical Management Agency Ltd $v$ The Commissioner of Patents [2000] 2 NZLR 529, 544 (CA). 
different "use" (that of active ingredients in making the drug) that was claimed. It also ignored the presence of "any" by allowing novelty to derive from second and subsequent medical uses.

Swiss-type claims break the rule that novelty must derive from the thing patented; a product claim must be for a novel product, a use claim must be for a novel use. It confounds common sense that a company, which has for decades manufactured a drug using an unchanging process, can somehow gain a fresh patent over that manufacturing process purely because a new use for the manufactured good is discovered. If anything, that company should receive a monopoly over the newly discovered use, but if they are precluded from doing so by the prohibition on patenting methods of medical treatment, this is no excuse for distorting patent law to satisfy their desire for protection.

With alarming success a drafting trick designed to benefit Switzerland's drug manufacturers has crept into the patent law regimes of several countries. Apart from the European, English, and New Zealand authorities already discussed, Swiss-type claims are accepted in, for example, Australia, ${ }^{70}$ South Africa, ${ }^{71}$ and Israel. ${ }^{72}$ The expansion has been characterised by a frustrating unwillingness to challenge the received "wisdom" of the EPO Enlarged Board of Appeals, a hesitancy partly attributable to the trend towards regional and international harmonisation of intellectual property laws. ${ }^{73}$

Regrettably, as more decisions in favour of Swiss-type claims mount it will become progressively harder for a non-timorous court to assert the better view that such claims lack novelty. The need for action is urgent because the window of opportunity to right Eisai's

70 See Bill Bennett "Australia: Intellectual Property - Recent Developments in Australian Intellectual Property Law" (1998) 20 EIPR N161.

71 See David G Sheppard "Case Comment: South Africa: Patents: Infringement - Second Medical Use" (1995) 17 EIPR D76, commenting on Elan Transdermal Ltd v Ciba-Geigy.

72 See Michael Cohn "Israel: Patents" (1993) 15 EIPR 81.

73 The ultimate outcome of this trend may be a global patent system. See, for example, Gerald J Mossinghoff "World Patent System Circa 20XX AD?" (1999) 1 Yale Symp L \& Tech 3 $<$ http://lawtech.law.yale.edu/symposium/99/speech_mossinghoff.htm> (last accessed 26 September 2000). 
wrong is closing. The EPO has not questioned Eisai, ${ }^{74}$ and has recently taken further moves to enshrine its decision by rewriting EPC Article 54(5) to read, ${ }^{75}$

Where the subject-matter of the invention is a substance or composition for use in a method referred to in Article 53(c), the substance or composition shall without prejudice to paragraphs 2 and 3 , be deemed to be new, provided that that use is not comprised in the state of the art.

This will remove the problem identified above with the use of "any". The change could be implemented as soon as the EPC diplomatic conference scheduled for December $2000,{ }^{76}$ and would represent a step towards entrenching Swiss-type claims. ${ }^{77}$

The spectre of legislative interference in favour of Swiss-type claims makes it imperative to discuss not only why these claims are illegal, but why they should be illegal. These arguments focus on issues of policy and practicality, and occupy the remainder of this essay.

\section{THE ARGUMENTS OF POLICY AND PRACTICE AGAINST SWISS-TYPE CLAIMS}

This part of the essay first explains that the decision whether Swiss-type claims should be accepted is essentially one of policy to be reached after considering all relevant factors. It is also argued that the final say on Swiss-type claims should come from the world's legislatures, rather than judiciaries. Following this preliminary discussion, the essay examines the various aspects and effects of Swiss-type claims which, in this author's opinion, demand they be disallowed.

74 In 1989 a request to refer to the Enlarged Board the question whether Eisai contradicted the EPC's wording and intentions was refused. See Gerald D Paterson "The Patentability of Further Uses of a Known Product Under the European Patent Convention" (1991) 13 EIPR 16, 18, referring to unpublished Case T297/88, dated 5 December 1989.

75 Draft Basic Proposal For Revision of The European Patent Convention, $46<\mathrm{http}$ ///www3.european-patentoffice.org/dwld/dipl_conf/pdf/ec00100_.pdf> (last accessed 30 September 2000). Note that the prohibition on method of medical treatment patents will be moved from Article 52(4) to Article 53(c).

76 See Mayall's IP Links <http://www.mayallj.freeserve.co.uk/european.htm\#revisions> (last updated 17 June 1999).

77 Note it would not solve the problem of extending a provision permitting product claims to permit Swiss-type claims, which are use (of chemicals to make drugs) claims. 


\section{A The Balancing Process and The Desirability of a Legislative Solution}

From the first national patent law, the Venetian Law of 1474, up to 1995 when the World Trade Organisation was established, the single guiding principle in all national patent laws and international conventions has been that public interest should have primacy over commercial interests. ${ }^{78}$ Clearly it is in the public interest for all people to have access to drugs needed to treat their ailments. The paradox is that it is also in the public interest to promote research and development by providing patent monopoly incentives. Therefore, whenever the extent of intellectual property protection is at issue, the answer of whether, and how far, protection should be extended is unavoidably a policy decision based on a judgment call of where to strike a balance between these interests. ${ }^{79}$ As Lockhart J said when considering method of medical treatment patents, ${ }^{80}$

Ultimately the resolution of this question is a balancing exercise. There is on the one hand a need to encourage research in connection with methods of medical treatment and on the other hand the need not unduly to restrict the activities of those who engage in the therapy of humans.

This balancing exercise requires a careful analysis of the competing social and economic factors at play in a particular jurisdiction. These factors, "are not necessarily the same for all countries." 81 On any one issue there will be several options to consider; for example, instead of prohibiting patents on methods of medical treatment a nation could introduce a defence of necessity, ${ }^{82}$ introduce compulsory licensing laws, or reduce the term of such patents. ${ }^{83}$ Where possible, a legislative answer to these issues is preferable because, "courts are certainly not the

78 Consumers International: Trade, Patents \& Health "Trade Briefing Paper No 4" (1999) <http://www.consumersinternational.org/trade/trade_brief/trade-health.html> (last accessed 30 September 2000).

79 JM Aubrey "A Justification of the Patent System" Phillips J (ed) Patents in Perspective (ESC Publishing, Oxford, 1985) 6.

80 Anaesthetic Supplies Pty Ltd $v$ Rescare Ltd (1994) 122 ALR 141, 156 (FCA).

81 Pharmaceutical Management Agency Ltd $v$ The Commissioner of Patents [2000] 2 NZLR 529, 532 (CA).

82 See Steven L Nichols "Hippocrates, The Patent-Holder: The Unenforceability of Medical Procedure Patents" (1997) 5 Geo Mason L Rev 227, 260.

83 Although this would only mitigate, rather than solve, the problems posed by method of medical treatment patents by squeezing their operation into a shorter time-frame, see Chris J Katopis "Patients v Patents?: Policy Implications of Recent Patent Legislation" (1997) 71 St John's L Rev 329, 359. 
appropriate forum for addressing the broad policy questions raised by the ... patent debate." 84 In Wellcome, McMullin J said, "patent law is a rather artificial, highly complex and somewhat refined subject. It involves scientific and commercial features outside everyday experience and the knowledge of the courts. Therefore, any major thrust should be left to Parliament." 85

The wisdom of this was made apparent by the Court of Appeal's approach in Pharmac. The parties presented typical "research incentive versus open dissemination" arguments. After admitting that the Court faced a "complexity of economics", 86 Gault J recorded that Gallen J in the High Court believed the opposing positions were "equally supportable". ${ }^{87}$ The matter was then dropped without further discussion. So, when faced with difficult, competing socioeconomic arguments for and against Swiss-type claims, the Court preferred to let them "cancel each other out" rather than give them serious consideration.

The courts have ignored the balance-point struck by the EPC's negotiators on the issue of subsequent medical use patents. Article 54(5) enshrined the judgment call that a known substance should be patentable one more time, and only one more time, following discovery of a medical use. This contradicted the prohibition on method of medical treatment patents, but still represented a stance on how far this prohibition would be undermined. Against this background, the argument that because there is no essential difference between the discovery of a first, second or third medical use, therefore all should be capable of supporting a fresh patent, is misguided. It misses the point that the decision to differentiate between these discoveries is not based on legal principle, but on policy considerations.

A similar argument of law, seemingly supported by Gault $\mathrm{J}$ in Pharmac, ${ }^{88}$ is that since patents over surgical equipment and new drugs are acceptable, surely those based on new methods of using drugs are also acceptable. Again this fails to appreciate that discrimination

84 Robert M Portman "Legislative Restriction on Medical and Surgical Procedure Patents Removes Impediment to Medical Progress" (1996) 4 Uni Balt IP LJ 91, 111, citing Diamond v Chakrabarty (1980) 447 US 303, 318, "matter[s] of policy [are] for resolution within the legislative process after the kind of investigation, examination, and study that legislative bodies can provide and courts cannot."

85 Wellcome Foundation Ltd $v$ Commissioner of Patents [1983] NZLR 385, 398 (CA).

86 Pharmaceutical Management Agency Ltd $v$ The Commissioner of Patents [2000] 2 NZLR 529, 532 (CA).

87 Pharmaceutical Management Agency Ltd $v$ The Commissioner of Patents [2000] 2 NZLR 529, 533 (CA).

88 Pharmaceutical Management Agency Ltd v The Commissioner of Patents [2000] 2 NZLR 529, 538 (CA), referring to the distinction as "illogical". 
between these patent types is the result of balancing the competing considerations before consciously selecting a particular location at which to draw the line of patentability. ${ }^{89}$

These considerations resulted in the "first medical use only" balancing point framed in Article 54(5). Instead of this rule, Pharmac committed New Zealand to an alternative balancing point first proposed by a country with a world-class pharmaceutical industry and ratified by courts unconcerned with arguments as to its practical consequences. Under this approach, the potential number of drug-manufacturing monopolies greatly increases. Virtually all of these monopolies will be owned by foreign companies, and the fact that New Zealand is, by a very great measure, a net importer of intellectual property suggests we should have thought twice before adopting Switzerland's position.

Another reason for hoping that the world's legislatures will re-take the issue out of the courts' hands is that the original approval of Swiss-type claims emanated from as high an authority as the EPO's Enlarged Board of Appeals. Therefore, as mentioned above, the hands of lower courts are frustratingly tied. Sadly Pharmac, a decision of a national appellate court, will probably have a similar roll-on effect in future unless Parliament, or a brave court in another jurisdiction, intervenes. The remainder of this essay canvasses six reasons why this intervention should occur.

\section{B Swiss-Type Claims Undermine The Prohibition on Patenting Methods of Medical Treatment}

\section{Why is this prohibition necessary?}

Patents are a species of intellectual property, and carry the corollary rights of ownership such as the right of exclusive use. ${ }^{90}$ These rights are granted to inventors as a reward for their

89 For further reasons on why patents over medical products are distinguished from patents over methods of treatment, see Philip Culbert "Patent Law Reform in New Zealand: Should Methods of Medical Treatment be Patentable?" (1997) 5 Patent World 32, 38.

90 Todd Martin "Patentability of Methods of Medical Treatment: A Comparative Study" (2000) 82 J Pat \& Trademark Off Soc'y 381, 381. However, the rights attaching to intellectual "property" are not absolute, and so it is perhaps more appropriate to view intellectual property rights as "quasi-property". 
work and as an incentive for others to do likewise. ${ }^{91}$ Thus patents are fundamentally concerned with legal rights and the provision of financial incentives.

Medicine, in contrast, is a realm where professionalism and ethics generally triumph over selfish temptations to assert legal rights. ${ }^{92}$ Despite the introduction of free-market reforms to many countries' health sectors, including New Zealand's, the romantic notion persists that the art of medicine is not motivated by economics: ${ }^{93}$

It is well known that the medical profession do all in their power to discourage members of their body from obtaining protection for any discovery that has for its object the alleviation of human suffering, and it is impossible to speak too highly of such conduct, ... .

Extending patent protection into the medical world only introduces a new and dangerous economic motivation to medical practitioners, a motivation which carries with it the right to monopolise aspects of the healing arts.

A good example of the dangers posed by medical patents is provided by recent happenings in the United States. American courts have taken a liberal approach to patentability, "anything under the sun that is made by man", 94 can qualify. In conjunction with decisions of the US Patent and Trademark Office, ${ }^{95}$ the American medical profession thus operates without any prohibitions on patenting methods of medical treatment. ${ }^{96}$ Instead, the monopolisation of medical breakthroughs has been minimised by the powerful ethical ideal of sharing information which might advance the profession's ultimate aim of improving the human

91 See, for example, HI Dutton The Patent System and Inventive Activity During The Industrial Revolution 1750-1852 (Manchester University Press, Manchester, 1984) 17-29; Cornish Intellectual Property and Allied Rights (2 ed, Sweet \& Maxwell, England, 1989) para 3.024.

92 See Martin v Wyeth Inc (1951) 96 F Supp 689 (D Md).

$93 \operatorname{Re} C \mathcal{E} W^{\prime}$ s Application (1914) 31 RPC 235 (HL) per Lord Buckmaster.

94 Diamond v Chakrabarty (1980) 447 US 303, 309, holding that genetically engineered micro-organisms are patentable.

95 The leading decision is Ex Parte Scherer (1954) 103 USPQ (BNA) 107 (Pat Off Bd App).

96 Note that in 1902 and 1903, the US Congress considered, without passing, "a Bill amending the statutes relating to patents, relieving medical and dental practitioners from unjust burdens imposed by patentees holding patents concerning methods and devices for treating human diseases, ailments, and disabilities." See Robert M Portman, "Legislative Restriction on Medical and Surgical Procedure Patents Removes Impediment to Medical Progress" (1996) 4 Uni Balt IP LJ 91, footnote 10 and accompanying text. 
condition. ${ }^{97}$ But several doctors recently broke this trust in a series of dismaying decisions to abuse the availability of patent protection, contrary to the spirit of the Hippocratic Oath. Most notoriously, Dr Sam Pallin patented a method of making a v-shaped, "self-suturing" scalpel incision during cataract surgery. He then prosecuted another doctor for writing an article about "his" method. ${ }^{98}$ This and similar cases ${ }^{99}$ illustrate the danger of asserting intellectual property rights in the medical arena. Under then-existing American law, patentees like Dr Pallin could terrorise other doctors with demands for royalties and threats of lawsuits, unacceptably fettering their choice of how best to diagnose disease and treat their patients.

Fear of these stifling conditions has led almost all Western jurisdictions to introduce a prohibition on patenting methods of medical treatment either through statute or case-law. ${ }^{100}$ One of the first Commonwealth cases addressing this issue was $\operatorname{Re} C \mathcal{E} W^{\prime}$ s Application, ${ }^{101}$ where a patent over a process of extracting metals from living bodies (particularly lead from humans) was refused. This essay has already discussed the statutory prohibition in Europe and England, and the New Zealand approach is described below. Elsewhere, Canada's leading authority is Tennessee Eastman Co $v$ Commissioner of Patents ${ }^{102}$, where a method of binding wounds with a polymer was held non-patentable. ${ }^{103}$ The prohibition is also sanctioned in international conventions other than the EPC. Article 27(3) of the TRIPs agreement permits member states to, "exclude from patentability ... diagnostic, therapeutic and surgical methods

97 See generally the discussion in Martin $v$ Wyeth Inc (1951) 96 F Supp 689, 695 (D Md).

98 Pallin $v$ Singer (1993) 36 USPQ (2d) 1050 (Vt). Note that Pallin's patent was invalidated for obviousness and lack of novelty after the defendants produced evidence showing that another ophthalmologist had performed more than 375 of the sutureless surgeries in the month before Dr Pallin's claimed invention date.

99 For example, in 1991, Dr John Stephens patented a method of identifying male and female genitalia in ultrasound images in order to determine an unborn foetus' gender. This patent was denounced since, "holding a patent for foetal anatomical sex assignment is rather like holding a patent for telling the difference between the right hand and the left hand." See "The War Over Method Patents: Mine, Yours, Ours" [1994] 10 ARGUS 8.

100 For a general overview of the history of the prohibition, see David Kell "Expanding the Frontier of Patentability: Methods of Medical Treatment of the Human Body" (1995) 17 EIPR 202.

101 Re C E W's Application (1914) 31 RPC 235 (HL).

102 Tennessee Eastman Co v Commissioner of Patents, (1972) 8 CPR (2d) 202 (SCC).

103 See further Todd Martin "Patentability of Methods of Medical Treatment: A Comparative Study" (2000) 82 J Pat \& Trademark Off Soc'y 381, 417-418. 
for the treatment of humans or animals." Similar wording exists in Article 1709(3)(a) of the North American Free Trade Agreement.

The glaring exception is Australia. In Joos $v$ Commissioner of Patents, 104 Barwick CJ concluded that since medicine was a field as economic as any other, methods of medical treatment were capable of industrial application. Although the court appeared to distinguish cosmetic treatments (patentable) from therapeutic treatments (non-patentable), the decision was still ambiguous as to whether the prohibition actually existed. ${ }^{105}$ But in Anaesthetic Supplies Pty Ltd v Rescare Ltd ${ }^{106}$ ("Rescare"), Lockhart and Wilcox JJ said in obiter dicta that since nothing in the Patents Act 1990 expressly precluded methods of medical treatment patents, they should be allowed. The dissenter, Sheppard J, preferred to reject all such patents on public interests grounds. The picture was temporarily clouded by Heerey J in Bristol-Myers Squibb Co $v$ FH Faulding \& Co Ltd, ${ }^{107}$ who adopted Sheppard J's dicta in invalidating a patent over a method of administering taxol. ${ }^{108}$ However, the Full Federal Court recently overturned this part of Heerey J's judgment, but again, since the patent was invalidated for other reasons their approval of medical method of treatment patents was obiter dicta. ${ }^{109}$ Despite the lingering legal uncertainty, the Australian Commissioner of Patents asserted that method of medical treatment patents will to be accepted. ${ }^{110}$

Despite pressure from lobbyists, including the Medical Procedure Patent Coalition and the American Medical Association, the United States has not introduced a general ban on method

104 Joos v Commissioner of Patents (1972) 126 CLR 611.

105 David Kell "Expanding the Frontier of Patentability: Methods of Medical Treatment of the Human Body" (1995) 17 EIPR 202, 203.

106 Anaesthetic Supplies Pty Ltd v Rescare Ltd, (1994) 122 ALR 141 (FCA), affirming Rescare Ltd v Anaesthetic Supplies Pty Ltd (1992) 111 ALR 205 (FCA) per Gummow J.

107 Bristol-Myers Squibb Co v FH Faulding \& Co Ltd (1998) 41 IPR 467 (FCA).

108 The patent was the same as faced by the English court in Bristol-Myers Squibb Co $v$ Baker Norton Pharmaceuticals Inc [1999] RPC 253, 258-259 (UK Pat Ct); (23 May 2000) LEXIS 2000 WL 664521 (EWCA).

109 Bristol-Myers Squibb Co v F H Faulding \& Co Ltd (2000) 170 ALR 439 FCA) paras 12-18, 142.

110 Bill Bennett "Australia: Intellectual Property - Recent Developments in Australian Intellectual Property Law" (1998) 20 EIPR N161. 
of medical treatment patents. ${ }^{111}$ However, a "tacked-on" provision of the Fiscal Year 1997 omnibus spending bill insulated doctors and hospitals from liability by introducing a law preventing patentees from bringing suits based upon, "a medical practitioner's performance of a [patented] medical activity". ${ }^{112}$ The shortcoming of this immunity is that it only applies to medical techniques and procedures; patents on the use of drugs are still enforceable against medical practitioners. ${ }^{113}$ Since patents for the use of known drug $\mathrm{X}$ in treating disease $\mathrm{Y}$ are enforceable, Swiss-type claims are unnecessary in the United States.

It is submitted that the prohibition on patenting methods of medical treatment, including methods involving no more than administering a dosage of a drug, is desirable. The rapid advances in medicine during the twentieth century were largely attributable to the free exchange of medical practitioners' inventions and discoveries. The American Medical Association regards this traditional sharing of knowledge as an ethical duty: ${ }^{114}$

Physicians have an obligation to share their knowledge and skills and to report the results of clinical and laboratory research. This exchange improves the quality of patient care through early evaluation of technological advances and rapid dissemination of improvements, greatly benefiting the health and welfare of society. The intentional withholding of new medical knowledge, skills, and techniques from colleagues for reasons of personal gain is detrimental to the medical profession and to society and is to be condemned.

The New Zealand Medical Association's Code of Ethics similarly implores medical practitioners to, "totally avoid the use of secret remedies", and to, "[e]nsure that any new therapeutic or diagnostic method is described through professional channels and the benefits,

111 Perhaps the term "reintroduced" would be more appropriate. The US Patent and Trademark Office used to refuse method of medical treatment patents. See, for example, Ex parte Brinkerhoff (1883) 24 Dec Comm'r Pat 349 (USPTO), where it was said, "[t]he methods or modes of treatment of physicians of certain diseases are not patentable...". The USPTO's stance was adopted in early judicial decisions. See, for example, Morton $v$ New York Eye Infirmary (1862) 17 F Cas 879 (SD NY), invalidating a patent for the use of ether as an anaesthetic during surgery.

112 Patents Act 35 USC s 287(c).

113 Patents Act 35 USC § 287(c)(2)(A).

114 Robert M Portman "Legislative Restriction on Medical and Surgical Procedure Patents Removes Impediment to Medical Progress" (1996) 4 Uni Balt IP LJ 91, 104, citing "Opinion on New Medical Procedures" in Code of Medical Ethics, Current Opinions of the AMA Council on Ethical and Judicial Affairs (1994) s 9.08. 
if proved, made available to the profession at large." ${ }^{115}$ Profit motives are also frowned upon; "standards of care should not be compromised in order to meet financial or commercial targets whether these are set by a doctor personally or by an organisation."116

Jacob J's judgment in $B M S$ is cited several times in this essay with approval. However, one aspect which causes concern is his apparent doubt that the prohibition is necessary. His Honour said, ${ }^{117}$

The thinking behind the exception is not particularly rational: if one accepts that a patent monopoly is a fair price to pay for the extra research incentive, then there is no reason to suppose that that would also apply to methods of treatment. It is noteworthy that in the US any such exception has gone, and yet no-one, so far as I know, suggests that its removal has caused any trouble.

In this author's opinion, the uproar following the Pallin litigation, specifically the profession's alarm at patentees' ability to stifle peer review and sabotage effective health care, plus Congress's rapid moves to mitigate the prohibition's effects by insulating medical practitioners from liability, does show that the prohibition is beneficial and the previous American approach, troublesome.

\section{The prohibition in New Zealand}

In Commissioner of Patents $v$ The Wellcome Foundation ${ }^{118}$ the Wellcome Foundation sought to patent the use of malaria drugs for treating meningeal leukemia. Davison CJ allowed the patent in the High Court, ${ }^{119}$ but the Court of Appeal reversed in a judgment which became New Zealand's leading authority on the prohibition. In reaching this result, Cooke J, as he then was, said, "[t]here remains ... a deep-seated sense that the art of the physician or the surgeon in alleviating human suffering does not belong to the area of economic endeavour or trade and commerce." 120

115 New Zealand Medical Association Code of Ethics <http://www.nzma.org.nz/about/ethics.rtf> (last accessed 30 September 2000).

116 New Zealand Medical Association Code of Ethics <http://www.nzma.org.nz/about/ethics.rtf> (last accessed 30 September 2000).

117 Bristol-Myers Squibb Co v Baker Norton Pharmaceuticals Inc [1999] RPC 253, 274 (UK Pat Ct).

118 Wellcome Foundation Ltd $v$ Commissioner of Patents [1983] NZLR 385 (CA).

119 Wellcome Foundation v Commissioner of Patents [1979] 2 NZLR 591 (HC).

120 Wellcome Foundation Ltd v Commissioner of Patents [1983] NZLR 385, 388 (CA). 
Previously, several legal arguments were made against medical method of treatment patents. Primarily, new uses of known products were not considered "inventions", defined as "methods of new manufacture". This argument was laid to rest in NRDC (discussed above), and in Wellcome, Cooke J recognised that, "the suggestion in part of the argument for the Commissioner that a discovery of a new use for a known product cannot provide a basis for a grant must, in its bald form, be rejected as outmoded."121

Another legal argument against medical method of treatment patents arose from the definition of "invention" as a method of new manufacture within section 6 of the Statute of Monopolies 1623. Section 6 excluded manners of new manufacture, "contrary to the law [or] mischievous to the state by raising prices of commodities at home, or hurt of trade, or generally inconvenient". ${ }^{122}$ There was room to argue that being "contrary to law or morality" or "generally inconvenient" was thus a legal bar to patentability. ${ }^{123}$ But the view taken in Pharmac was that "contrary to law or morality" and "generally inconvenient" were only grounds on which the Patent Commissioner, in their discretion, could reject applications. ${ }^{124}$

Finally, since section 51 of the Patents Act 1953 provided for the compulsory licensing of patented products used in medicine without mentioning method of medical treatment patents, the inference was that such patents could not exist. Gault J noted some pre-1977 English support for this inference, but since section 51 was repealed in 1992, he considered the argument moot. ${ }^{125}$

With all legal reasons circumvented, the prohibition on patenting methods of medical treatment in New Zealand rests solely upon policy and ethical grounds. ${ }^{126}$ The prohibition today is not absolute, since methods of treating animals, as opposed to humans, are

121 Wellcome Foundation Ltd v Commissioner of Patents [1983] NZLR 385, 388 (CA).

122 Statute of Monopolies 1623 (Eng), s 6.

123 See Joos $v$ Commissioner of Patents (1972) 126 CLR 611, 623 per Barwick CJ, suggesting in obiter dicta that method of medical treatment patents are generally inconvenient.

124 Pharmaceutical Management Agency Ltd $v$ The Commissioner of Patents [2000] 2 NZLR 529, 535 (CA).

125 Pharmaceutical Management Agency Ltd $v$ The Commissioner of Patents [2000] 2 NZLR 529, 538 (CA).

126 Pharmaceutical Management Agency Ltd $v$ The Commissioner of Patents [2000] 2 NZLR 529, 538 (CA). See also Eli Lilly \& Company's Application [1975] RPC 438, 445 (Pat App Trib) per Graham and Whitford JJ "the reasons for such an exclusion appear to us to be based in ethics rather than logic." 
patentable, ${ }^{127}$ as are a host of non-necessary or cosmetic types of human treatment. ${ }^{128}$ But the core prohibitions on patenting methods of therapeutic treatment, ${ }^{129}$ including surgery, ${ }^{130}$ and methods of diagnosis, ${ }^{131}$ remain.

\section{How do Swiss-type claims undermine the prohibition?}

The Pallin litigation illustrates the sobering truth that despite the strong tradition in the medical world of sharing treatment methods, rogues like Dr Pallin cannot be trusted to elevate social and ethical concerns above their proprietary and financial interests. Another group which cannot be trusted to further the practice of medicine for the good of humanity, rather than for their own pockets, are drug manufacturers. There are many examples to illustrate this. Swiss pharmaceutical giant Hoffman La Roche recently conspired to fix vitamin prices, resulting in a record US $\$ 500$ million dollar fine paid to the US Department of Justice ${ }^{132}$ and a $\$ 632$ million payout to settle a class-action civil suit. ${ }^{133}$ Drug manufacturers Parke-Davis, Dainippon, and Rhone-Poulenc Rorer (RPR), discontinued research into much-needed tuberculosis antibiotics because these drugs would be "unprofitable". ${ }^{134}$ When Novartis contributed \$25 million to Berkeley University's Department of Plant and Microbial Biology's in exchange for first rights to their discoveries, they gagged researchers from publishing the

127 Swift \& Company's Application [1960] NZLR 775 (SC).

128 Pharmaceutical Management Agency Ltd $v$ The Commissioner of Patents [2000] 2 NZLR 529, 537 (CA), where Gault J presents a non-exhaustive list of patentable medical treatments.

129 "Therapy" means, "any treatment which is designed to cure, alleviate, remove or lessen the symptoms of, or prevent or reduce the possibility of contracting any disorder or malfunction of the human or animal body": Cornea (1995) OJ EPO 512, Case T 24/91.

130 "Surgery" means, "the field of medicine involving the healing of diseases or accident injuries, or remedies against physical defects by means of a surgical intervention performed on a body": Rainer Moufang "Methods of Medical Treatment Under Patent Law" (1993) 24 IIC 18, 37.

131 "Diagnosis" means, "recognition, differentiation and localisation of pathological conditions": Rainer Moufang "Methods of Medical Treatment Under Patent Law" (1993) 24 IIC 18, 45.

132 John C Hammell "Pharmaceutical Giants Threaten Health Freedom" <http://www.toyourhealthmagazine.com/Pharm_Giantsx.html> (last accessed 30 September 2000).

133 "The Fix Is In: Cartels Beware" Chemical $\mathcal{E}$ Engineering News, 21 February 2000, <http://www.drrath.com/menue/news_content/usa/aktuell-usa/2000_03_16_01.htm> (last viewed 22 September 2000)

134 Myrna E Watanabe "The Urge To Merge" The Scientist, 2 October 1995, <http://www.thescientist.com/yr1995/oct/merger_951002.html> (last accessed 22 September 2000). 
benefits of their discoveries. Steven Rosenberg, of the US National Cancer Institute, observed, "one of the most basic tenets of science is that we share information in an open way. As biotech and pharmaceutical companies have become more involved in funding research, there's been a shift toward confidentiality that is severely inhibiting the interchange of information." 135 Rosenberg experienced this first-hand when a pharmaceutical giant refused to tell him safe-dosage levels for an agent used in his experimental cancer treatment. Finally, in "Corporate Crime in the Pharmaceutical Industry", Dr John Braithwaite, a UK Trade Practices Commissioner, wrote, "[i]nternational bribery and corruption, fraud in the testing of drugs, criminal negligence in the unsafe manufacturing of drugs - the pharmaceutical industry has a worse record of law-breaking than any other industry."136

Swiss-type claims provide another example; their raison d'etre is to circumvent, through clever wording, the prohibition on patenting methods of medical treatment. As Aldous J observed in BMS, "[t]he claim is an unsuccessful attempt to monopolise the new method of treatment by drafting it along the lines of the Swiss-type claim."137 Buxton LJ went even further in characterising Swiss-type patent as a disguised form of method of medical treatment patent: "[i]f the novelty can lie in the nature of use, rather than in the end-result at which that use aims, then it is indeed the method of treatment on which patentability rests." 138 These quotes suggest that Swiss-type claims directly contravene the prohibition, but the better view is that they undermine it by promoting the very mischief the prohibition counters: restricting medical practitioners' choice of treatments.

The potential for Swiss-type claims to cause this mischief has escaped the courts' awareness. In Pharmac, Gault J believed that because Swiss-type patents only protect the drug manufacturing process, and not the actual use of the drug in a method of medical treatment,

135 Jennifer Washburn "The Kept University" Atlantic Monthly, March 2000 <http://www.newamerica.net/articles/Washburn/washburnAM3.00.htm> (last accessed 22 September 2000).

136 John Braithwaite Corporate Crime in the Pharmaceutical Industry (Routledge \& Kegan Paul, London, 1984).

137 Bristol-Myers Squibb Co v Baker Norton Pharmaceuticals Inc (23 May 2000) LEXIS 2000 WL 664521 (EWCA) para 63.

138 Bristol-Myers Squibb Co v Baker Norton Pharmaceuticals Inc (23 May 2000) LEXIS 2000 WL 664521 (EWCA) para 83. 
they will not fetter the medical profession. ${ }^{139}$ Since only companies guilty of duplicating drugs for the medical market would be liable, and not doctors themselves, Gault J thought Swiss-type claims consistent with the spirit, as well as the letter, of the prohibition on medical treatment patents.

This argument is superficially attractive, but flawed. It ignores the practical reality that manufacturing monopolies can constrain a drug's supply to the point where doctors face real problems in acquiring that drug. Restrictions on a drug's availability can fetter the medical profession in the same way as restrictions on a drug's use. This was recognised in Eli Lilly $\mathcal{E}$ Co's Application, ${ }^{140}$ a case not cited in the European, English or New Zealand cases on Swisstype claims. There, the applicant was, "prepared to ... disclaim any right to stop doctors or hospitals treating human beings with the applicant's compound", 141 seeking only a monopoly over manufacture, sale, supply and importation (not use). The Patents Appeal Tribunal said, ${ }^{142}$

It seems to us therefore that in a case where the alleged invention is based on the discovery of unexpected curative properties of known compounds care must always be taken to examine the form of the claim actually made. The matter must be looked at as one of substance and if the conclusion is that whatever the precise form of words used the true effect of the claim will be to prevent the manufacture or supply of the compounds in question for the purpose of treating illness or disease in human beings, then the claim must be refused. [emphasis added]

Swiss-type claims create a manufacturing monopoly where the drug's sole supplier is the patentee and its licensees. While product claims for genuinely new drugs and for "pharmaceutically pure forms" of known substances create similar monopolies, the added drawback of Swiss-type claims is that they allow a single drug to support multiple, subsequent monopolies, one for each new use, and can tie the hands of doctors for a longer period of time.

139 Pharmaceutical Management Agency Ltd $v$ The Commissioner of Patents [2000] 2 NZLR 529, 538-539 (CA). "Can invention in the discovery of a new pharmaceutical use be protected in such a way as to leave unrestrained the medical practitioner in the practice of his or her diagnostic, therapeutic or surgical methods? In Europe the Swiss-type use claim serves as the means of achieving such protection."

140 Eli Lilly \& Company's Application [1975] RPC 438 (Pat App Trib).

141 Eli Lilly \& Company's Application [1975] RPC 438, 443 (Pat App Trib) per Graham and Whitford JJ.

142 Eli Lilly \& Company's Application [1975] RPC 438, 445 (Pat App Trib) per Graham and Whitford JJ. 
In Rescare, Sheppard J recognised the dire consequences of restricting the availability of methods of treatment, 143

It is not going too far, I think, to say that the Court should not contemplate the grant of letters patent which would give to one medical practitioner, or perhaps a group of medical practitioners, a monopoly over, for example, a surgical procedure which might be greatly beneficial to mankind. Its denial might mean the death or unnecessary suffering of countless people. I cannot think that this is really what the medical profession as a whole would seek to achieve. Its whole history is a denial of this proposition.

Death and suffering can also arise from limiting a drug's supply sources through Swisstype claims. The current legal battle in South Africa surrounding the availability of AIDS drugs provides a topical illustration of the consequences of drug-manufacturing monopolies.

One in seven South Africans harbours the HIV virus. Few of those that develop AIDS can afford treatment; the cost of the latest medications is approximately five times the annual per capita income. ${ }^{144}$ Adding to their pain is the fact that much cheaper AIDS medications exist, "but a 1995 trade agreement designed to protect companies' intellectual property rights has kept them out of the hands of South African doctors."145

Under pressure and criticism, drug manufacturers have made well-publicised "efforts" to find a solution. For example, in May 2000 the world's top five drug manufacturers offered to cut certain drug prices in Africa by up to 85 percent. ${ }^{146}$ These offers were rejected because they were perceived as public relations exercises designed to hide the drug firms' true, crippling

143 Anaesthetic Supplies Pty Ltd v Rescare Ltd (1994) 122 ALR 141, 180 (FCA) per Sheppard J (dissenting).

144 Mike McKee "Tripping Over TRIPs" IP Magazine, September 1999 <http://www.ipww.com/ monthly/99-sept/trip.html> (last accessed 30 September 2000). See also Donald G McNeil Jr "Medicine Merchants: As Devastating Epidemics Increase, Nations Take On Drug Companies" New York Times, New York, United States, 9 July 2000, which relates the story of a Kenyan police officer on a monthly salary of $\$ 43$. The drug fluconazole, needed to cure his otherwise terminal condition, costs $\$ 18$ per pill, meaning that a full supply would cost $\$ 540$ a month. A cheaper generic version, made in Thailand in violation of drug manufacturer Pfizer's patent, costs sixty cents.

145 Mike McKee "Tripping Over TRIPs" IP Magazine, September 1999 <http://www.ipww.com/monthly/ 99-sept/trip.html> (last accessed 30 September 2000).

146 The companies were Merck, Hoffman La Roche, Bristol-Myers Squibb, Boehringer Ingelheim and Glaxo Wellcome. See Donald G McNeil Jr "Companies to Cut Cost of AIDS Drugs for Poor Nations" New York Times, New York, 12 May 2000. 
stance $^{147}$ and to delay the passage of laws permitting the wholesale avoidance of AIDS-drug patents. ${ }^{148}$ The offer was also conditional on the African nations stopping all imports of even cheaper generic versions of the drugs from countries which ignore international patent treaties (such as India, Bangladesh and Brazil). ${ }^{149}$ Another example is Pfizer's recent undertaking to provide its anti-fungal AIDS-drug fluconazole free to poor South Africans. While ostensibly generous, this announcement only came on the same day that a lawsuit and picketing campaign which would have embarrassingly denounced the company as an AIDS profiteer were due to start. ${ }^{150}$

Instead of relying on the superficial, face-saving offers of drug manufacturers to avoid a human catastrophe, the South African government took matters into its own hands. In 1997 the Medicines and Related Substances Control Act was amended to permit compulsory licensing and parallel importation of cheaper generic versions of AIDS drugs. The result has been ongoing litigation, ${ }^{151}$ supported by drug manufacturers, which has paralysed the country's attempts to assist its citizens.

The whole affair illustrates how patent law is directly responsible for the dearth of affordable AIDS drugs, resulting in immeasurable suffering. Jeffrey Trewhitt, spokesman for the Washington, DC-based Pharmaceutical Research and Manufacturers of America, captures the manufacturers' legalistic attitude, "[South Africa] could set a very, very bad precedent that

147 Daniel Berman, coordinator of international group Medecins Sans Frontieres' campaign for access to essential medicines, says, "we feel strongly that piecemeal donations and pilot projects are not going to do it. This is a crisis and it needs crisis responses": Steven Swindells "South Africa: Drug Firms Face Fight on Generic AIDS Drugs" Reuters, 13 July 2000.

148 Rachel L Swarns "Loans to Buy AIDS Drugs Are Rejected by Africans" New York Times, New York, 22 August 2000.

149 "South Africa's Mbeki appeals for quick action in AIDS fight" CNN.com, 22 May 2000 <http://www.cnn.com/2000/WORLD/africa/05/22/safrica.mbeki> (last accessed 30 September 2000).

150 Donald G McNeil Jr "Medicine Merchants: As Devastating Epidemics Increase, Nations Take On Drug Companies" New York Times, New York, 9 July 2000.

151 Marjolein Harvey "Pharmaceuticals Resume Litigation Against Government on Medicines Act" WOZA Internet, Johannesburg, 1 August 2000. The Notice of Motion in The Pharmaceutical Manfacturers' Association of South Africa et al $v$ The President of the Republic of South Africa et al High Court of South Africa (Transvaal Provincial Division) Case 4183/98 <http://www.cptech.org/ip/health/sa/ pharmasuit.html> (last accessed 22 September 2000). 
could undermine legitimate patent protection around the world ... ."152 More pointedly, Mirryena Deeb, CEO and chief lobbyist of the South African Pharmaceutical Manufacturers Association (comprised mainly of subsidiaries of American and European companies) said that if South Africa passed the law they would be cut off from all new drug discoveries. In 1998, an interviewer asked her if the South African Pharmaceutical Manufacturers Association was literally threatening to let thousands of South Africans die. Her reply: "in so many words, yes." 153 The industry's dispassionate adherence to its legal rights has also been observed in Thailand, which passed compulsory licensing laws similar to those South Africa desires. Dr Korn Dabbarensi, Thailand's health minister, asked, "how "humane" are these manufacturers? They are talking to me about the profits of their company against the lives of my people."154

Consumers in developed countries also face risks from drug manufacturing monopolies. In 1995, David Mowery wrote an article saying that because only four private, wholly US-owned firms supplied vaccines to the American populace, a natural disaster, fire, or war eliminating even one of these competitors could gravely impact public health. ${ }^{155}$ Similarly Swiss-type claims, by preventing the development of alternative sources of supply, increase the risk that a particular society may one day find needed drugs unavailable.

In summary, Swiss-type claims create drug manufacturing monopolies which restrict the supply of drugs and are thus equally harmful as those experienced in Africa. They reduce medical practitioners' choice of treatments and thus undermine the prohibition on method of medical treatment patents. A Resolution of the World Health Assembly passed in May 1999 urged industrialised nations, "to ensure that public health interests are paramount in pharmaceutical and health policies", 156 something which weighs heavily against Swiss-type

152 Mike McKee "Tripping Over TRIPs" IP Magazine, September 1999 <http://www.ipww.com/ monthly/99-sept/trip.html> (last accessed 30 September 2000).

153 Donald G McNeil Jr "Medicine Merchants: As Devastating Epidemics Increase, Nations Take On Drug Companies" New York Times, New York, 9 July 2000.

154 Donald G McNeil Jr "Medicine Merchants: As Devastating Epidemics Increase, Nations Take On Drug Companies" New York Times, New York, 9 July 2000.

155 David C Mowery "Improving the Reliability of the US Vaccine Supply: An Evaluation of Alternatives" (1995) 20 J Health Politics, Policy \& Law 973.

156 Consumers International: Trade, Patents \& Health "Trade Briefing Paper No 4" (1999) <http://www.consumersinternational.org/trade/trade_brief/trade-health.html> (last accessed 30 September 2000. 
claims. Of course, if all patents that restricted the supply of needed medical products were rejected, it would mean the death of all patents for drugs and medical equipment. But if the balancing exercise described above is conducted, this outcome would be highly unlikely given that it contains no compromise recognition of the public interest in promoting drug research. However, allowing Swiss-type claims tilts the balance too far in the opposite direction.

\section{Swiss-Type Claims Create "Bad Monopolies" Because They Provide a Superfluous Incentive}

\section{Good and bad monopolies}

In a 1993 article, Alan White defined "bad" patent monopolies as possessing one of two characteristics. Either the patent removes from the public domain something the public already possessed, a danger which the requirement of novelty seeks to avoid, or it removes from the public domain something the public could have had without giving the inventor a patent incentive. ${ }^{157}$ This second branch is what renders the monopolies granted through Swiss-type claims "bad". Swiss-type claims provide a superfluous research incentive. Indeed they were not even introduced to promote research but to protect the privileged position of established pharmaceutical companies while ensuring them super-profits beyond what could be reaped if only one patent were available for each drug manufacturing process. This motive is natural in a privatised, market driven industry that for decades has benefited from patent laws developed not in answer to the needs and plights of the "public", but rather on nationalistic, self-serving grounds. ${ }^{158}$

\section{Intellectual property protection as an economic tool}

The Unites States Constitution grants Congress the power, "to promote the progress of science and useful arts, by securing for limited time to authors and inventors the exclusive right to their respective writings and discoveries." 159 This is the most famous enunciation of the "betterment of society" motivation which theoretically underpins intellectual property law. The arrival of Swiss-type claims is a bitter reminder that all too often intellectual property laws are introduced and adapted for far less idealistic reasons.

157 Alan W White "The Function and Structure of Patent Claims" (1993) 15 EIPR 243, 243.

158 For a brief discussion of how patent law now encourages the concentration of wealth rather than beneficial innovation, see D Vaver "Intellectual Property Today: Of Myths and Paradoxes" (1990) Can Bar Rev 98, 116.

159 United States Constitution, art 1, s 8, cl 8. 
Copyright law provides a well-known example. From 1557 to 1694 the Licensing Act assured the Stationers' Company a monopoly over printing and publishing in England. When the Act expired, the Stationers moved to secure their financial position by petitioning Parliament to pass the Statute of Queen Anne in 1710, 160 the world's first statutory copyright law. ${ }^{161}$ The Stationers used the authors as a figurehead of sympathy. Although in law the authors received exclusive rights of exploitation, in reality the printers and publishers, as assignees of those rights, truly benefited. The common law's entire copyright system was thus introduced not for the stated purpose of encouraging creativity, but to satisfy a particular group's thirst for monopoly rents.

Developments in patent law have also been driven by money-seeking behaviour. Switzerland's approval of Swiss-type claims greatly benefited their economy because it granted giant Swiss-based drug companies such as Novaris and Hoffman La Roche the ability to gain new patents for making old drugs. The history of Swiss patent law reveals other manipulations of national patent laws. In the nineteenth century, during a period of rapid industrialisation and liberalisation of trade in Europe, Switzerland rejected national patents altogether. When Switzerland signed the Paris Convention for the Protection of Industrial Property (in force since 1883) they took full advantage of the provision permitting signatories to determine areas of non-patentability. ${ }^{162}$

Patent laws are traditionally regarded as a spur to development and growth, ${ }^{163}$ but the Swiss recognised that patent protection would actually stifle their fledgling pharmaceutical industry. ${ }^{164}$ By persistently refusing to patent drugs, Switzerland ensured Swiss drug manufacturers years of borrowing, testing and improving upon foreign inventions. Some of the

160 "An Act for the Encouragement of Learning and for Securing the Property of Copies of Books to the Rightful Owners Thereof".

161 RV Bettig Copyrighting Culture: The Political Economy of Intellectual Property (Westview Press, United States, 1996) 17-18.

162 E Schiff Industrialisation Without National Patents: The Netherlands 1869-1912, Switzerland 1850-1907 (Princeton University Press, United States, 1971).

163 See, for example, HI Dutton The Patent System and Inventive Activity During The Industrial Revolution 1750-1852 (Manchester University Press, Manchester, 1984) 17-29; Cornish Intellectual Property and Allied Rights (2 ed, Sweet \& Maxwell, England, 1989) para 3.024.

164 The inhibiting nature of patent law is discussed in D Vaver "Intellectual Property Today: Of Myths and Paradoxes" (1990) Can Bar Rev 98, 115-116. 
earliest "defectors" were French chemists who relocated in the resource-rich areas around Basel. These chemists brought with them the secret formulae of the dye industry, and it was on the back of this industry that the Swiss pharmaceutical giants rose to prominence. ${ }^{165}$ Switzerland only allowed pharmaceutical patents in 1977, when its own industry had reached a mature stage of development.

Less than ten years after allowing pharmaceutical patents, Switzerland's Patent Office increased their scope by ushering in Swiss-type claims. One factor which may have accelerated their acceptance in Europe is the push by Japanese drug manufacturers to take market share away from their European and American competitors. The Japanese government has targeted the world pharmaceutical industry for domination. ${ }^{166}$ Author Takayuki Yamamoto observes that, "the way the industry is gearing up its research and development engine and looking hungrily at overseas markets is faintly reminiscent of the auto industry 40 years ago."167 Tomonori Miki, executive director of Anyo Corporation contributed the warning that Europe, "may be heading toward a pharmaceutical war."168

Swiss-type claims thus appear to be the latest in a series of patent law developments based not on assisting public health but on preserving and increasing the industry's profits. The same motive drives other developments in the pharmaceutical world. Since 1993, pharmaceutical companies have invested over US $\$ 80$ billion dollars in mergers and acquisitions. ${ }^{169}$ Some examples are the mergers of American medicine manufacturers Cynamide and Wyeth Laboratories in 1997, Swiss pharmaceutical giants Ciba-Geigy and Sandoz to form Novartis in

165 "Chemical Industry Continues to Invest in Research" The Washington Times, Washington DC, 20 January $20000<$ http://www.washtimes.com/internatlads/switzerland/20.html> (last accessed 4 May 2000).

166 Rachel F Ochs "Pharmaceuticals: The Battle for Control in the 21 ${ }^{\text {st }}$ Century" (1996) 10 J Law \& Health 297.

167 Takayuki Yamamoto,"Japan's Drug Makers - Tomorrow's Trade Warriors" Tokyo Business Today, July $1994,35$.

168 Rachel F Ochs, "Pharmaceuticals: The Battle for Control in the 21 ${ }^{\text {st }}$ Century" (1996) 10 J Law \& Health 297, 299.

169 Financial Investment Advisory Service "Special Supplement: Strategies of Pharmaceutical Multinationals" March 1996 <http://www.fias.net/pubs/fdinews/v1n2/supp.html> (last accessed 22 September 2000). 
1996, ${ }^{170}$ and the proposed merger of British giants Glaxo Wellcome and SmithKline Beecham. ${ }^{171}$ In 1995, American venture capitalist Larry Bock, founder of a dozen biotechnology firms, observed that these mergers, "were done more for sales and marketing reasons", than for promoting research and advancing the companies' basic missions. ${ }^{172}$

At issue is the commodification of the patent system and the redefinition of patent attorneys as "intellectual property asset managers". This buzz-phrase reflects how patents are no longer perceived as state-granted rewards or incentives, but as privately owned assets to be managed and exploited for profit. ${ }^{173}$

The strong evidence that financial gain motivates advocates of Swiss-type claims indicates that they do not exist or operate to promote research.

\section{The absence of Swiss-type claims would not stifle research}

The respondents in Pharmac trotted out the stock argument that Swiss-type claims make medical advances possible by allowing companies to recoup their research costs. This argument presumes its own truth and suffers from the fatal defect that, ${ }^{174}$

It is simply no more than the barest of hypothesis. There is ... little or no empirical data to support the proposition that research and investment in new methods of medical treatment would not proceed in the same manner and to the same degree without a patents incentive as they would with one.

In Pharmac, the pointed rebuttal of the respondents' argument was that every single second medical use discovery in the history of mankind has occurred without the need for a patent incentive. This includes the period of rapid medical advances between World War II and the

170 George Skaria "The Odd Couple" Business Today, 11 July 1998 <http://www.indiatoday.com/btoday/07111998/ma.html> (last accessed 22 September 2000).

171 Marian Jones "As Drug Companies Merge, Will Consumers Be Left Crying in the Aisles?" 3 February $2000<$ http://www.foxnews.com/health/020300/drugmerge.sml> (last accessed 22 September 2000).

172 Myrna E Watanabe "The Urge To Merge" The Scientist, 2 October $1995<$ http://www.thescientist.com/yr1995/oct/merger_951002.html> (last accessed 22 September 2000).

173 Wendy Davis "Lawyers Turning Patents Into Profits" New York Law Journal, 25 September 2000.

174 Patricia Loughlan "Of Patents and Patients: New Monopolies in Medical Methods" (1995) 5 Aus IPJ 13. 
late 1970s. ${ }^{175}$ In BMS Jacob J said, "I am of course aware of the policy reasons behind ... Eisai, namely encouragement of research ... [but] in any event it is not self-evident that the decision in Eisai ... [has] in fact encouraged research."176

Another reason why Swiss-type patents are superfluous is the existence of alternative forms of spurring and rewarding discoveries of new uses for drugs. Not all discoveries are made by huge multi-nationals, and for the individual practitioner, Western medical systems have their own internal reward-systems, including recognition and respect through publication and awards. ${ }^{177}$ Grants provide another source of research funds. "Where capital is needed, grants from the federal government and non-profit organisations generally have been available to finance these efforts. Thus, there is simply no persuasive evidence that physicians and others require an additional proprietary incentive to conduct research ...."178 The ability of grants to spur research cannot be dismissed as wishful thinking. ${ }^{179} \mathrm{New}$ medical uses for drugs will mostly be discovered in Western nations with governments, charities or philanthropists wealthy enough to afford such payments. Furthermore, it should not be difficult for Western governments to re-deploy money for such grants. The American government, for example, currently spends less than two percent of its research and development budget on the medical field. Spending on aerospace, computers and electronics research is far greater because of their importance for defence. ${ }^{180}$

Drug manufacturers themselves could lessen the need for third party funding by increasing their own research expenditure. President Clinton blasted the American pharmaceutical industry for spending one billion dollars more on advertising than on research. ${ }^{181}$

175 Todd Martin "Patentability of Methods of Medical Treatment: A Comparative Study" (2000) 82 J Pat \& Trademark Off Soc'y 381, 383.

176 Bristol-Myers Squibb Co v Baker Norton Pharmaceuticals Inc [1999] RPC 253, 280 (UK Pat Ct).

177 Todd Martin "Patentability of Methods of Medical Treatment: A Comparative Study" (2000) 82 J Pat \& Trademark Off Soc'y 381, 384.

178 Robert M Portman "Legislative Restriction on Medical and Surgical Procedure Patents Removes Impediment to Medical Progress" (1996) 4 Uni Balt IP LJ 91, 111.

179 For a sceptical view of the efficacy of a state-sponsored reward system, see DP O'Brien "Patents: An Economist's View" in J Phillips (ed) Patents in Perspective (ESC Publishing, Oxford, 1985) 32-41.

180 Claudio Tarabusi and Graham Vickery "Globalization and Pharmaceuticals" [1994] 12 OEDC Observer.

181 Rachel F Ochs "Pharmaceuticals: The Battle for Control in the 21 ${ }^{\text {st }}$ Century" (1996) 10 J Law \& Health 297,336 . 
Dr Schondelmeyer, Professor of pharmaceutical economics at the University of Minnesota, estimated that drug manufacturers spend sixteen percent of their budget on promotion, eight times more than what other consumer-based companies spend. ${ }^{182}$

These considerations suggest that Swiss-type patent monopolies are "bad" because their existence does not prompt research, or to put it another way, their absence would not reduce the amount of research. Those unconvinced by this argument might perhaps find an alternative suggestion palatable; the inclusion of "substantial research and development expenditure" as a fourth condition of patentability. ${ }^{183}$ While guidelines for applying this test, including checks against inflated expenditure claims, would be required, this proposal represents another option for the world's legislatures to consider.

\section{Swiss-Type Claims Support Patents That Are Difficult to Enforce}

In many cases a drug's new use will involve applying it to a patient using the same series of physical steps already existing in the state of the art. For example, aspirin is applied in the same way regardless of whether the aim is to relieve pain or lessen the risk of heart attacks. Thus Swiss-type claims will often rely on a mere "novelty of purpose", as the drug's manufacturing and application process will be identical to that in the state of the art. Eisai allowed such "novelty of purpose" to support Swiss-type claims in the medical arena, but it was not until the EPO Enlarged Board of Appeals decided Mobil Friction Reducing Additive ${ }^{184}$ ("Mobil") that the grave difficulties arising from deriving novelty in this manner entered the spotlight.

\section{Mobil}

Mobil concerned a compound originally added to lubricating oil to prevent rust in vehicles' engines. Later it was discovered that the compound also reduced engine friction. The Enlarged Board allowed a new patent over the compound's old use (addition to lubrication oil), with the requisite novelty being derived from the new purpose. This was despite the fact that

182 Rachel F Ochs "Pharmaceuticals: The Battle for Control in the 21 ${ }^{\text {st }}$ Century" (1996) 10 J Law \& Health 297, 336 .

183 Beata Gocyk-Farber "Patenting Medial Procedures: A Search for a Compromise Between Ethics and Economics" (1997) 18 Cardozo L Rev 1527, 1558.

184 Mobil Friction Reducing Additive [1990] OJ EPO 93, Case G02/88. 
consumers had unwittingly benefited from the additive's friction-reducing side-effect for years. The Enlarged Board said, 185

With respect to a claim to a new use of a known compound, such new use may reflect a newly discovered technical effect described in the patent. The attaining of such a technical effect should then be considered as a functional technical feature of the claim (eg the achievement in a particular context of that technical effect). If that technical feature has not been previously made available to the public by any of the means set out in article 54(2) EPC, then the claimed invention is novel, even though such technical effect may have inherently taken place in the course of carrying out what has previously been made available to the public." [emphasis added]

The patent was purpose-limited, in that only people who added the compound to oil for the purpose of reducing friction (as opposed to reducing rust), would infringe. It is this point around which most of the criticism of Mobil circulates. By sanctioning patents based on a mere novelty of purpose, Mobil raised difficult questions of enforcement. Regardless of whether a person wishes to reduce friction or to reduce rust, the physical actions of adding the additive to oil will be identical. How then can the patentee prove that a particular use of the additive breached their monopoly over using the additive for a certain purpose? And what if a person used the additive with both purposes in mind? Would liability to the patentee turn on whether the patented purpose was the "dominant" purpose, if it was a "substantial" purpose, if it was merely present in the infringer's mind, or on some other arbitrary test?

\section{The connection between Mobil and Swiss-type claims}

The criticisms of Mobil are applicable to Swiss-type claims despite the Enlarged Board's insistence that Mobil was unrelated to Eisai. They sought to differentiate Eisai as being based on the specific interplay between Articles 52(4) and 54(5) of the EPC. The English Court of Appeal judges in BMS shared this view, Aldous LJ stating, "I do not believe that the Mobil case qualifies or amplifies the conclusion reached in Eisai."186 However, there is an obvious point of similarity: in cases where the new treatment purpose of a known drug requires administration identical to that which has been done before, a Swiss-type claim will also rely solely upon a "novelty of purpose". This led Jacob J to say in BMS, ${ }^{187}$

185 Mobil Friction Reducing Additive [1990] OJ EPO 93, Case G02/88, para 10.3.

186 Bristol-Myers Squibb Co v Baker Norton Pharmaceuticals Inc (23 May 2000) LEXIS 2000 WL 664521 (EWCA) para 41.

187 Bristol-Myers Squibb Co v Baker Norton Pharmaceuticals Inc [1999] RPC 253, 277 (UK Pat Ct). 
It is arguable that there is no logical or reasonable distinction between [Mobil] and the decision in Eisai. After all it is the novel (second medical use) purpose of the product of manufacture of the Swiss-type claim which is said to create novelty. The product and its method of manufacture are old. So to try to steer a course between accepting Eisai and yet holding Mobil wrong is at best going to involve more Byzantine logic.

\section{The difficulties of enforcing Swiss-type claims}

It is easy to see how the difficulties, identified in the wake of Mobil, with enforcing patents based on novelty of purpose could manifest themselves following a Swiss-type claim. Gault J observed in Pharmac that, "[a Swiss-type claim] is not a product claim because a combination of the active compound and the carrier not made for the purpose of producing a cancer treatment medicine would not infringe. Nor would sale of the combination for other purposes ...." 188 This is too simplistic a view of the situation. It fails to appreciate the huge difficulties a patentee would face in showing whether a rival company was manufacturing a drug for the patented purpose, as opposed to another, non-patented purpose.

Difficulty might be avoided if the rival drug manufacturer was selling its products to consumers who clearly required the drugs for the patented purpose. Returning to our aspirin example, it might prima facie infringe a Swiss-type claim based on aspirin's use against heartattacks if a rival company made aspirin and sold them to a cardiac treatment clinic. But in this author's opinion it is unlikely that a court would base liability on this evidence alone. The clinic could have used the aspirin for the non-patented purpose of relieving their patients' general aches and pains. Furthermore, it would not necessarily follow from the clinic's intention to use the aspirin against heart attacks that the manufacturer made the aspirin with that purpose in mind. Liability would be even less likely if the aspirin were sold to a distributor, wholesaler, hospital or other entity from which an intention to use the drug in a particular way could not be implied.

The rival drug company's packaging of the drug would be evidence of infringement if the package contained, or had written upon it, instructions for the use of the drug in the newly discovered method of treatment. It would be easy, however, for the rival company to restrain itself from committing such self-incrimination. It could sell its product to a separate distribution and packaging company, taking care that any decision on how to market and package the drug could not be attributed back to it.

188 Pharmaceutical Management Agency Ltd $v$ The Commissioner of Patents [2000] 2 NZLR 529, 546 (CA). 
Gerald Paterson describes another difficulty in enforcing Swiss-type claims, ${ }^{189}$

If a document such as a published patent discloses a first use of a product, a question could arise as to whether a patentee of a subsequently filed ... patent claiming a second use of that product could successfully allege infringement by the first patentee ..., if the carrying out of such first use also necessarily and unavoidably involves carrying out the second use as well. This question could arise in either a medical or non-medical context, following either Eisai or Mobil.

It is not hard to imagine a drug that, like the additive in Mobil, has two or more simultaneous effects. If these effects are discovered at different times by different companies, Swiss-type claims would allow them to each gain a monopoly over the manufacture of the drug for the purpose of the use they discovered. How would the courts decide whether any or all of the companies should be liable for continuing to manufacture the "multi-purpose" drug? Quite possibly, in the situation where a drug has two simultaneous effects, a Swiss-type patent holder could threaten another company with legal action for doing no more than what it was doing before that patent's priority date. ${ }^{190}$

In Pharmac, Gault J pointed out that, "infringement depending on the state of mind or purpose of the alleged infringer is not unknown to the patent law", relying upon the example of, "the exclusion from infringement for the benefit of those practising [an] invention for the purpose of bona fide research." 191 However, this situation can be distinguished because evidence of the alleged infringer's subjective purpose of bona fide research will be provided by the infringer themselves. Conversely, in an action for breach of a Swiss-type patent, it is the patentee who must prove the alleged infringer's subjective purpose in manufacturing a drug. Gault J's assertion that the law already deals with infringement based on the infringer's subjective state of mind was therefore misguided as it overlooked the extra difficulty arising from the patentee having to prove the infringer's state of mind.

Gault J also believed the alleged difficulties with enforcing Swiss-type claims were, "more apparent than real", because, "under the Medicines Act 1981 the manufacture and sale of medicines is closely regulated. The development, trialing, registration, manufacture and distribution of a medicine will be unlikely to give rise to difficulties in identifying the purpose

189 Gerald D Paterson "The Patentability of Further Uses of a Known Product Under the European Patent Convention" (1991) 13 EIPR 16, 20.

190 Alan W White "The Novelty-Destroying Disclosure: Some Recent Decisions" (1990) 12 EIPR 315, 320.

191 Pharmaceutical Management Agency Ltd $v$ The Commissioner of Patents [2000] 2 NZLR 529, 546 (CA). 
for which it is intended."192 Under section 20(2) of the Medicines Act 1981, new medicines cannot be sold or advertised without the Minister of Health's consent. Section 21(2) requires that the manufacturer or importer's application for consent specify, "the purposes for which the medicine will be recommended to be used, and the claims or representations to be made in respect of its usefulness." Under section 24 , any change or addition to a medicine's represented purposes must be notified to the Director-General in writing.

While this somewhat allays the fear that the purpose in a drug manufacturer's mind will be unknowable, it does not resolve the issue. First, the disclosure provisions in sections 20 and 21 do not apply to medicines that were generally available in New Zealand before the Act. Secondly, the Act does not require all the possible purposes of a drug to be disclosed, only those which the manufacturer or importer intends to publicise. Once the new medical use of a drug becomes known, there would be no need for the manufacturer or importer to expressly recommend their drug for that use and so the Act could be avoided. For example, an importer of aspirin could avoid infringing a Swiss-type patent on manufacturing aspirin for treating heart attacks by only recommending its use to treat pain and swelling. The drug's purchasers would know that aspirin could be used for reducing the likelihood of heart attacks, but if they did use the drugs for this purpose there would be no way to attribute this back to the manufacturer. Thirdly, even where a consent application includes within the list of recommended purposes the patented purpose, there is still the issue of whether the patented purpose has to be dominant, or substantial, or merely present, in the manufacturer's mind for infringement to occur.

\section{Judicial ignorance of the difficulties posed by Mobil and Eisai}

Unfortunately these practical difficulties were ignored in Eisai, Wyeth \& Schering, Pharmac, and Mobil. In Eisai the Enlarged Board said, "[i]t is particularly important to bear in mind that Article 64(3) leaves the question of infringement to be dealt with by national law." ${ }^{193}$ In Mobil, national infringement laws were deemed irrelevant to questions of patentability because of a distinction between the protection and rights conferred by a patent, 194

There is a clear distinction between the protection that is conferred and the rights that are conferred by a European patent ... . The protection conferred by a patent is determined by the terms of the

192 Pharmaceutical Management Agency Ltd $v$ The Commissioner of Patents [2000] 2 NZLR 529, 546 (CA). 193 Re Eisai Co Ltd [1985] OJ EPO 64, Case GR 05/83, para 18.

194 Mobil Friction Reducing Additive [1990] OJ EPO 93, Case G02/88, para 3.3. 
claims (Article 69(1) EPC) ... . In this connection, Article 69 EPC and its Protocol are to be applied, both in proceedings before the EPO and in proceedings within the Contracting States .... In contrast, the rights conferred on the proprietor of a European patent (Article 64(1) EPC) are the legal rights which the law of a designated Contracting State may confer upon the proprietor, for example, as regards what acts of third parties constitute infringement of the patent, and as regards the remedies which are available in respect of any infringement." [emphasis added]

This separation of "validity" and "infringement" was highly unsatisfactory because it left patentability to be determined without consideration of whether the patent would, in practical terms, be enforceable. ${ }^{195}$

In my view it is essential for the granting authority to consider fully the implications of the claims it grants in relation to both validity and scope. It is not helpful to take a view on validity (particularly novelty) which simply leaves intractable problems for an infringement court - and for the public who need to know what they can and cannot do.

Mobil thrust these problems into the spotlight and so it, rather than Eisai, has been the predominant target of criticism. 196

I should only add that it is apparent that the decision in Mobil is causing considerable difficulty to national courts. It is not good enough for these difficulties to be brushed aside, as for instance was done by Mr Paterson (a member of the Mobil Enlarged Board) in extra-judicial lectures ... and in an article in the European Intellectual Property Review. Substantive European patent law demands a holistic approach to infringement and validity. Moreover by virtue of the EPC ... it should have it. For myself, although I have no power of direct reference ... I hope that the EPO will find a way of convening a fresh Enlarged Board (ideally including judges with experience of infringement) to reconsider Mobil." [emphasis added]

Fortunately there are indications that Jacob J's "holistic approach" is growing in favour. A decision of the EPO's Technical Board of Appeals not to allow claims in the Swiss-type based on newly discovered uses for surgical equipment was partly based on the difficulty of proving whether a piece of equipment was manufactured for one use or another. ${ }^{197}$

195 Bristol-Myers Squibb Co v Baker Norton Pharmaceuticals Inc [1999] RPC 253, 272 (UK Pat Ct) per Jacob J. 196 Bristol-Myers Squibb Co v Baker Norton Pharmaceuticals Inc [1999] RPC 253, 280 (UK Pat Ct) per Jacob J.

197 See the European Patents Handbook (2 ed, 1996) Rel 24, point 3.5.2(B). 
In summary, if Mobil and Eisai remain good law, patents based on mere novelty of purpose will proliferate, with the test of infringement focusing on the infringer's subjective state of mind. ${ }^{198}$ One likely consequence is that infringement of Swiss-type patents will be extremely difficult to identify, and those patents hard to enforce. It has been said that when a case based squarely on the infringement of a Swiss-type claim finally comes before the courts, "one cannot ... be certain that claims of this form will be upheld in such contested inter partes pleadings."199 In the meantime, the difficulties of enforcement generated by patents based on novelty of purpose provide yet another reason for leaning away from their recognition.

Finally, it is worth remembering that a dominant factor in various courts' decisions to follow Eisai has been the aura of authority enjoyed by the EPO's Enlarged Board of Appeals. The Mobil decision provides good reason for opening the Board's decisions to more assertive challenge. One positive sign was the UKPO's decision in Crane Ltd's ${ }^{200}$ that openly doubted whether Mobil applied under English patent law. Unfortunately this was overshadowed by Merrell Dow Pharmaceuticals Inc v HN Norton $\mathcal{E}$ Co $L t d,{ }^{201}$ in which the House of Lords declined an opportunity to disapprove of Mobil. Yet there remains hope that the general outcry engendered by Mobil may spur future courts to cast a critical eye upon the same troublesome consequences generated by the EPO's acceptance of Swiss-type claims.

\section{E Swiss-Type Claims Allow Patents to be Granted For Mere Discoveries}

\section{The invention versus discovery dichotomy}

The EPC specifically excludes from patentability, "a discovery, scientific theory, or mathematical model."202 The UKPO's Patent Practice Manual (December 1999) identifies another problem with allowing Swiss-type claims in that, "the fact that a known material or article is found to have hitherto unknown properties is a discovery and not an invention."203

198 Alan W White, "The Novelty-Destroying Disclosure: Some Recent Decisions" (1990) 12 EIPR 315, 320.

199 Alan W White "The Function and Structure of Patent Claims" (1993) 15 EIPR 243, 248.

200 Crane Ltd's Application (1992) SRIS O/40/92, discussed in Alan W White "The Function and Structure of Patent Claims" (1993) 15 EIPR 243, 249.

201 Merrell Dow Pharmaceuticals Inc v HN Norton \& Co Ltd [1996] RPC 76 (HL).

202 EPC, art 52(2)(a).

203 Manual of Patent Practice [in the United Kingdom Patent Office] (4 ed, December 1999) para 1.14 <http://www.patent.gov.uk/dpatents/mpp/manual.html> (last viewed 29 September 2000). 
One reason why the patent in BMS was disallowed was because, "noticing that the ... threehour infusion caused less neutropenia is a mere discovery." ${ }^{204}$ [emphasis added]

The distinction between patentable inventions and non-patentable discoveries invokes the same principle as the idea versus expression dichotomy in copyright law. ${ }^{205}$ Discoveries simply uncover existing facts and supposedly contain no element of intellectual creativity. ${ }^{206}$ But the weakness is disallowing patents on this ground is that the mere recognition of previously unknown properties of known substances can amount to a valuable contribution to the state of the art. Often these discoveries will be the result of great work and expenditure, and under Lockean theory, which states that every person is entitled to property in the fruits of their labour, ${ }^{207}$ this alone justifies a patent grant. Lockean theory is responsible for the "sweat of the brow" doctrine accepted in England ${ }^{208}$ and, arguably, New Zealand. ${ }^{209}$ Although the United States rejects this doctrine, ${ }^{210}$ the fact that their patent legislation states, "[w]hoever invents or discovers any new and useful process, machine, manufacture, or composition of matter ... may obtain a patent therefore..." 211 [emphasis added], indicates that patentability will not turn on the invention versus discovery dichotomy.

The dichotomy is still useful in drawing attention to the fact that Swiss-type claims are based on discoveries which may contain little or no creative element. The true danger is monopolies based on insignificant advances.

204 Bristol-Myers Squibb Co v Baker Norton Pharmaceuticals Inc [1999] RPC 253, 279 (UK Pat Ct) per Jacob J

205 See generally Richard Gardiner "Language and the Law of Patents" (1994) 47 Current Legal Problems 255.

206 D Vaver "Intellectual Property Today: Of Myths and Paradoxes" (1990) Can Bar Rev 98, 117-118.

207 See RV Bettig Copyrighting Culture: The Political Economy of Intellectual Property (Westview Press, United States, 1996) 19-20.

208 See Ladbroke (Football) Ltd v William Hill (Football) Ltd [1964] 1 All ER 465 (HL); Weatherby \& Sons v International Horse Agency and Exchange Ltd [1910] 2 Ch 297. See generally Stanley Lai "Database Protection in the United Kingdom: The New Deal and its Effects on Software Protection" (1998) 20 EIPR 32.

209 See the guarded judgment in Telecom Corp of NZ Ltd $v$ Colour Pages Ltd (14 August 1997) unreported, High Court, Wellington CP 142/97 per McGechan J.

210 Feist Publications Inc v Rural Telephone Service Co Inc (1991) 111 S Ct 1282.

211 Patents Act 35 USC $\S 101$. 


\section{Swiss-type claims are open to abuse as companies may claim patents following insignificant advances}

The danger that Swiss-type claims may effectively protect insignificant advances has led the English Court of Appeal to narrow the scope of their application. The Swiss-type claim in $B M S$ was over the use of active ingredients to make a medicament to deliver taxol, after premedication, to patients over three hours. Buxton LJ said, ${ }^{212}$

It is important in this inquiry to remember the emphasis placed by the Board on justification by analogy from cases of first medical use. Recognition of first medical use as a subject of patentability necessarily entails the use of the substance for a new and completely different purpose from that in relation to which it is already known. If the Board"s analogy is to hold, therefore, the relationship between the first and the second medical use must be of the same nature: the second medical use must be for an end-purpose distinctively different from the first, albeit also medical, purpose for which the substance was used.

The Swiss-type claim in question was consequently disallowed because the new use, which differed only in the infusion's duration and the requirement for pre-medication, was too closely related to the known use. ${ }^{213}$

BMS does not, however, remove the possibility that by analogy with Mobil, the new medical treatment underlying a Swiss-type claim might be a mere side-effect of an existing treatment. A hypothetical example would be a Swiss-type claim based on the discovery that a drug for treating stomach cramps was unexpectedly effective in alleviating headaches. While it would undoubtedly benefit the public to have this knowledge, it remains highly questionable whether a patent over the production of that pill for the new use should be granted. Whereas development of the pill for its original use would have necessitated expenditure on formulation and testing, the subsequent discovery could quite easily have been made by accident. Again, the possibility of introducing a "substantial research and development

212 Bristol-Myers Squibb Co v Baker Norton Pharmaceuticals Inc (23 May 2000) LEXIS 2000 WL 664521 (EWCA) para 83.

213 This requirement was also alluded to in John Wyeth E Brother Ltd's Application Schering AG's Application [1985] RPC 545, 556 (UK Pat Ct) per Falconer J, stating that the case concerned, "the allowability of claims directed to an invention based on the discovery of a second (or subsequent) pharmaceutical use of a known substance or composition, already known for a particular medical use (or particular medical uses), the new use being unconnected with the previously known use or uses." [emphasis added]. 
expenditure" requirement of patentability ${ }^{214}$ might be useful in disqualifying patents based on truly non-creative discoveries.

\section{F Only Wealthy Corporations Can Make Use of Swiss-Type Claims}

Although the grant of a permissible type of patent should not depend upon the patentee's need for the associated financial gains, arguably the decision whether to disallow a type of patent altogether should account for the financial situation of its beneficiaries.

As with all patents in the pharmaceutical world, the requirement that an invention be capable of industrial application necessitates expensive clinical trials before a patent can be granted. Thus, "a clear indication that such a treatment has been tried and tested is essential to provide the necessary support for the claim." 215 For example, in 1996, Dr Wilhelm Hoerrman sought a Swiss-type patent following his discovery that a known composition of lysine and hydroxylysine was effective in treating a variety of inflammatory conditions including rheumatic fever, scarlatina and prostatitis. Dr Hoerrman was not professionally represented and fitted the romantic picture of the "individual inventor". His patent claim was refused because of the absence of, "any pharmacological-data to show that lysine or hydroxylysine is active against any of the ailments specified in the claims." ${ }^{216}$ Dr Hoerrmann was caught in the position that without a patent he could not afford clinical trials, yet without clinical trials, he could not receive a patent. The fact that the claim was of the Swiss-type also meant that greater-than-normal testing was expected in order to differentiate the new use from the state of the art. 217

This requirement excludes individual inventors and non-wealthy companies from the range of Swiss-type claims' potential beneficiaries, ${ }^{218}$ the very entities that patents should arguably benefit most. ${ }^{219}$

214 Beata Gocyk-Farber "Patenting Medial Procedures: A Search for a Compromise Between Ethics and Economics" (1997) 18 Cardoza L Rev 1527, 1558.

215 McManus's Application [1994] FSR 558 (UK Pat Ct).

216 Hoerrman's Application [1996] RPC 341, 344 (UKPO) per Mr Wood.

217 Hoerrman's Application [1996] RPC 341, 345 (UKPO) per Mr Wood.

218 See Prendergast's Application (7 July 1999) unreported, UK Patents Court, per Mr Justice Neuberger, where Dr Prendergast argued that the rejection of his patent on grounds of inadequate testing would make it very difficult for an individual or small company to succeed in making Swiss-type claims. The court accepted this as a true statement, but felt that this outcome was unavoidable. 
The important question is then whether the remaining beneficiaries truly need the additional financial benefits of Swiss-type claims. The answer is no. The global pharmaceutical industry has thrived for decades without these benefits, and "thrived" must be emphasised because the pharmaceutical industry is one of the world's richest. In 1999, "the pharmaceutical industry enjoyed profits of 18.6 percent of revenues, or nearly four times the median for Fortune 500 companies." 220 These super-profits are contentious. US Presidential candidate Al Gore commented, "these companies have so much power ... that they make campaign contributions and lobby and introduce these [patent extension] bills to extend the monopoly period", adding that any such patent protection extension would amount to an "unfair monopoly".221 Swisstype claims are themselves a variety of patent protection extension, and the wealthy status of the privileged few that will benefit from them undermines any argument that they are necessary.

\section{G Swiss-Type Claims Endanger Public Health}

Although a person making a Swiss-type claim must submit evidence of the new treatment's efficacy, where appropriate the tests conducted can be rudimentary rather than comprehensive. ${ }^{222}$ The danger is that to the lay public, the granting of a Swiss-type patent may be misunderstood as a governmental seal of approval. ${ }^{223}$ This means that ostensible validity can be accorded to a new method of treatment upon the judgment of a patent examiner rather than highly-trained medical experts.

Since Swiss-type patents deal with drugs already in circulation, the public will immediately be able to experiment with the claimed new use. This problem does not arise when dealing with product patents on new drugs, because each nation's health authorities, for example the US Food and Drug Administration, can still withhold the drug from the market pending more

219 DP O'Brien "Patents: An Economist's View" in J Phillips (ed) Patents in Perspective (ESC Publishing, Oxford, 1985) 32-41.

220 "Gore Assails Pharmaceutical Giants; Bush Considers Vice Presidential Contenders" 3 July 2000 <http://www.cnn.com/2000/ALLPOLITICS/stories/07/03/campaign.wrap> (last accessed 22 September 2000).

221 Mark Egan "Gore Blasts Drug Companies, Calls For Lower Price" Reuters, 28 August 2000.

222 Prendergast's Application (7 July 1999) unreported, UK Patents Court per Mr Justice Neuberger.

223 Robert M Portman "Legislative Restriction on Medical and Surgical Procedure Patents Removes Impediment to Medical Progress" (1996) 4 Uni Balt IP LJ 91, 106. 
extensive trials. But following the grant of a Swiss-type patent, and the publicity surrounding a claimed "breakthrough" cure, members of the public can buy the old drug and use it at the new (unproven) dosage levels with the new (unproven) treatment purpose in mind.

For example, in 1999, Australian rheumatologist Dr Henry Betts claimed to have discovered that lyprinol, an anti-arthritis drug extracted from green-lipped mussels, killed cancer cells in lab conditions. ${ }^{224}$ Since lyprinol was already in the marketplace, health authorities could only respond to the resulting media hype with warnings, they could not prevent people from buying and consuming lyprinol (and green-lipped mussels) in reliance upon the researchers' claims. ${ }^{225}$ The same blind trust following the grant of a Swiss-type claim could similarly lead to the widespread consumption of drugs for a use that has not withstood extensive scrutiny.

\section{CONCLUSION}

The centuries-old "research incentive versus widespread dissemination" debate will never be conclusively resolved because there will always be attractive arguments for both proponents and opponents of intellectual property. For this reason, on any particular issue the line between protection and non-protection can be drawn in several possible locations. The thrust of this essay is that on the issue of Swiss-type claims the line should tend towards the "widespread dissemination / non-protection" end of this conceptual scale, and should certainly be drawn with Swiss-type claims on the "non-protected" side.

The introduction of Swiss-type claims allows drug manufacturers to gain patents following what can be insignificant, non-creative contributions to the public domain. These claims can only benefit wealthy companies that need neither the resulting financial reward, nor the research incentive they supposedly bring. The difficulties in proving infringement of a Swisstype claim mean that their operation will be fraught with uncertainty and might unfairly expose companies to expensive litigation. Most alarmingly, these claims threaten public health by restricting the availability of needed drugs and by encouraging premature faith in the safety

224 See Penny Debelle "Mussells Linked to Cancer Relief" 31 July 1999
<http://www.smh.com.au/news/9907/31/text/national15.html> (last accessed 1 October
Chris Bullock "Cancer and the Propaganda of Hope" 10 October
<http://www.abc.net.au/rn/talks/bbing/stories/s59269.htm> (last accessed 1 October 2000).

225 The front page of the New Zealand Herald, dated 31 July 1999, quoted researcher Dr Henry Betts as saying, "this is the most exciting discovery of my career. If I was diagnosed with cancer, I would take as much Lyprinol as I could hold down". See Chris Bullock "Cancer and the Propaganda of Hope" 10 October 1999 <http:/ / www.abc.net.au/rn/talks/bbing/stories/s59269.htm> (last accessed 1 October). 
and effectiveness of new medical uses. Aside from these grave practical drawbacks, Swiss-type claims are legally deficient in that they draw legitimacy from an incorrect interpretation of the EPC and violate the general rule that the patentability requirement of novelty is satisfied only when the patent's subject-matter is novel. Sadly these reasons for rejecting Swiss-type claims have been ignored by courts unable to handle the complex socioeconomic arguments raised, or have fallen before the powerful ideal of conformity. Jacob J, referred to on appeal in BMS as, "a specialist judge in a specialist field", 226 is one of the resolute few that has challenged this trend and it is hoped that this essay may cause others to follow that lead.

226 Bristol-Myers Squibb Co v Baker Norton Pharmaceuticals Inc (23 May 2000) LEXIS 2000 WL 664521 (EWCA) para 116 per Holman J. 